Cover.--Low-altitude aerial photographs taken by F. W. Osterwald, 1975. Top, view southwest across the Navajo mine near Farmington, N. Mex. Dragline spoil piles in foreground were levelled and revegetated, leaving only the highwall and haulage roads to be reclaimed. Dragline shown stripping overburden in the dark-gray areas in upper left. Center, Belle Ayr mine near Gillette, Wyo. Caballo Creek in upper left is diverted around the pit. Coal bed 21 meters thick is being removed in two benches by shovels and trucks. Overburden is being removed at right center for stockpiling. Below storage silos and railroad loop, land disturbed by construction has been revegetated. Bottom, subsidence pits resulting from collapse of underground workings of the Monarch mine near Sheridan, Wyo. Overburden is mostly Pleistocene alluvium and less than 31 meters thick. Although some pits are old enough to have large trees growing in the bottoms, others are still forming; occasional fires and explosions are reported by local residents. The Monarch mine was abandoned in 1914. 


\title{
The Energy Lands Program of the U.S. Geological Survey, Fiscal Year 1976
}

\author{
By John O. Maberry, Compiler
}

GEOLOGICAL SURVEY CIRCULAR 778 


\section{United States Department of the Interior}

CECIL D. ANDRUS, Secretary

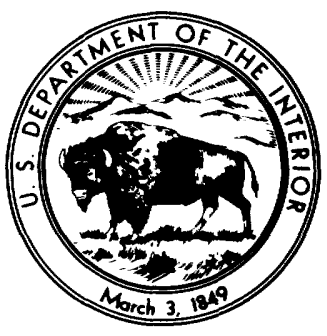

\section{Geological Survey}

W. A. Radlinski, Acting Director 
Structure of the Geological Survey Relative to the

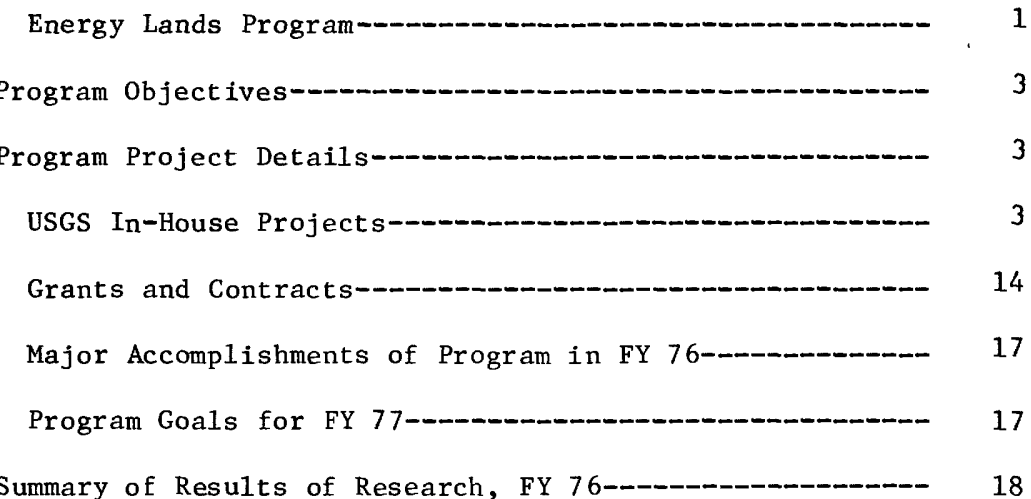

Stratigraphy and Paleoclimate of the Black Mesa Basin,

Reclamation-Potential Mapping of Strippable Coal

Lands in Semiarid Regions, by David W. Moore-_-_-_ 22

Surficial Geologic Mapping in the Eastern Powder

River Basin, by Donald A. Coates-_ 24

Geochemical Baselines, by Richard J. Ebens, Ronald

R. Tidbal1, James A. Erdman, Gerald L. Feder, and

Walter E. Dean-_-_-

Energy Lands Mapping in the Northwest Powder River

Basin, Wyoming, by S. P. Kanizay-

Landslide Mapping and Slope-Stability Analysis in

the Big Horn Quadrangle, Sheridan County, Wyoming,

by Walter F. Ebaugh 
Engineering Geophysical Investigations in the Powder

River Basin, Wyoming and Montana, by Carter $\mathrm{H}$.

Miller-_-1-

Regional Geotechnical Investigations, by Alan F.

Chleborad

Geotechnical Properties of the Fort Union and

Wasatch Formations, by Edward E. McGregor,

Richard A. Farrow, and Harold W. Olson--_-

Coal Mine Deformation, Western Powder River Basin,

by C. Richard Dunrud-_-

Stability of Highwalls in Surface Coal Mines, Western

Powder River Basin, by William Z. Savage and

William K. Smith--_-_-

Quaternary Chronology in Northwest Colorado Energy

Lands, by R. F. Madole-_-

Environmental Geologic Investigations in the

Kaiparowits Plateau, by K. A. Sargent

Water Resources Investigations in the Kaiparowits

Coal Basin Area, Utah, by Don Price--

The Improvement of Available Void Capacity of Soils

on Mine Spoils in Arid and Semiarid Regions, by

B. E. Munson, University of Denver-_-

Land Resources and Environmental Impact, East Texas

Lignite Belt, by John 0. Maberry- 
Figure 1. Diagram of structure of the Survey relative

$$
\text { to the Energy Lands Program- } 1
$$

2. Maps of Western Interior of the United States and Alaska, showing location of Energy Lands projects

3. Photograph of discovery tree of buried juniper forest in Dead Juniper Wash, Black Mesa, Arizona-_

4. Diagram of different types of terraced stratigraphy on Black Mesa- 20

5. Predictive model of climate records at Black Mesa-

6. Map of strippable coal, Campbell County, Wyoming, showing study area and existing or proposed mines

7. Six major environmental factors for reclamation-

8. Diagram showing main steps in preparation of composite map of reclamation potential--

9. Composite map of reclamation potential of strippable coal region

10. Index to surficial geologic mapping in progress, FY 76, eastern Powder River Basin 
Figure 11. USGS drilling crew sampling and instrumenting

a landslide in Wasatch Formation---_--------

12. Aerial photograph of large landslide in Fort Union Formation near Sheridan, Wyoming------

13. Index map of northern Powder River Basin showing locations of drill holes-----------

14. Typical geotechnical-properties log of drillhole B-1, Buffalo, Wyoming--_---_------

15. Photographs of effects of room-and-pillar mining, western Powder River Basin--------

16. Aerial photograph showing effects of past and present mining activities north of

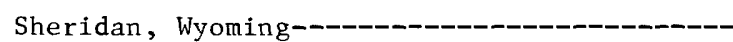

17. Photograph of deteriorated highwall of strip mine in Fort Union Formation south of

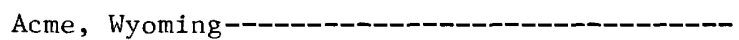

18. Map of geography and principal drainage system of the Kaiparowits coal basin,

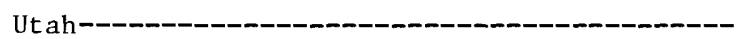

19. Map of eastern Texas, showing the extent of lignite-bearing formations--

\section{TABLE}

Table 1. Mapped surficial geologic units and underlying bedrock in the eastern Powder River Basin, Wyoming - 


\title{
The Energy Lands Program of the U.S. Geological Survey, Fiscal Year 1976
}

\author{
By John O. Maberry, Compiler
}

\section{ABSTRACT}

The Energy Lands Program of the U.S. Geological Survey comprises several projects that conduct basic and interpretive earthscience investigations into the environmental aspects of energy-resource recovery, transmission, and conversion. More than half the coal reserves of the United States occur west of the Mississippi River; therefore, the program concentrates mostly on coal-producing regions in the Western Interior. Additional studies involve the oil-shale region in Colorado, Wyoming, and Utah, and coal-related work in Alaska and Appalachia. The work is done both by USGS personnel and under USGS grants and contracts through the Energy Lands Program to universities, State Geological Surveys, and private individuals. Maps and reports characterizing many aspects of environmental earth science are being prepared for areas of Alaska, Montana, North Dakota, Wyoming, Utah, Colorado, New Mexico, Arizona, Oklahoma, Kansas, and Texas. Types of studies underway include bedrock, surficial, and interpretive geology; engineering geology, geochemistry of surface materials and plants; climatic conditions as they influence rehabilitation potential of mined lands; and feasibility of surface vs. underground mining. The purpose common to all investigations in the Energy Lands Program is to provide timely earth-science information for use by managers, policy-makers, engineers, scientists, planners, and others, in order to contribute to an environmentally sound, orderly, and safe development of the energy resources of the Nation.

\section{INTRODUCTION}

The Energy Lands Program began in 1975 as an outgrowth of the Geological Survey's contribution to the Northern Great Plains Resources Program and the Resources and Land Information Program Demonstration Project in the Powder River Basin. Since its inception, the Energy Lands Program has been part of the environmental aspects of energy program in the
Office of Environmental Geology, Geologic Division.

The program has grown slowly until, in Fiscal Year 1977, it supports the work of 38 geologists in the office of Environmental Geology and important investigations by the Branches of Regional Geochemistry and Isotope Geology, About 10 percent of program funds is dedicated to grants and contracts to non-USGS organizations helping to assess the environmental aspects of energy-resource recovery.

This circular is the first formal public report of progress by the program. Work and progress prior to Fiscal Year 1976 are recorded in adninistrative reports of the Geological Survey and in Geological Survey annual reports to State geologists.

STRUCTURE OF THE U.S. GEOLOGICAL SURVEY RELATIVE TO THE ENERGY LANDS PROGRAM

Geological Survey activities are supervised by the Director, who is supported by his staff of the Associate Director and five Assistant Directors (Land Resources, Energy and Mineral Resources, Environmental Conservation, Programs, and Administration; fig. 1). A wide variety of the Geological Survey's activities are drawn upon for support for the Energy Lands Program, and many Survey scientists use results of the program in their activities.

The basic structure of the Geological Survey comprises four operating Divisions (Geologic, Water Resources, Topographic, and Conservation) and three support Divisions (Computer, Publications, and Administrative). All divisions are headquartered at the USGS National Center in Reston, Va.

The Conservation Division supervises energy and mineral resource leasing and extraction activities on certain Federal lands. The Topographic Division is the Government's principal mapmaker, producing topographic and 


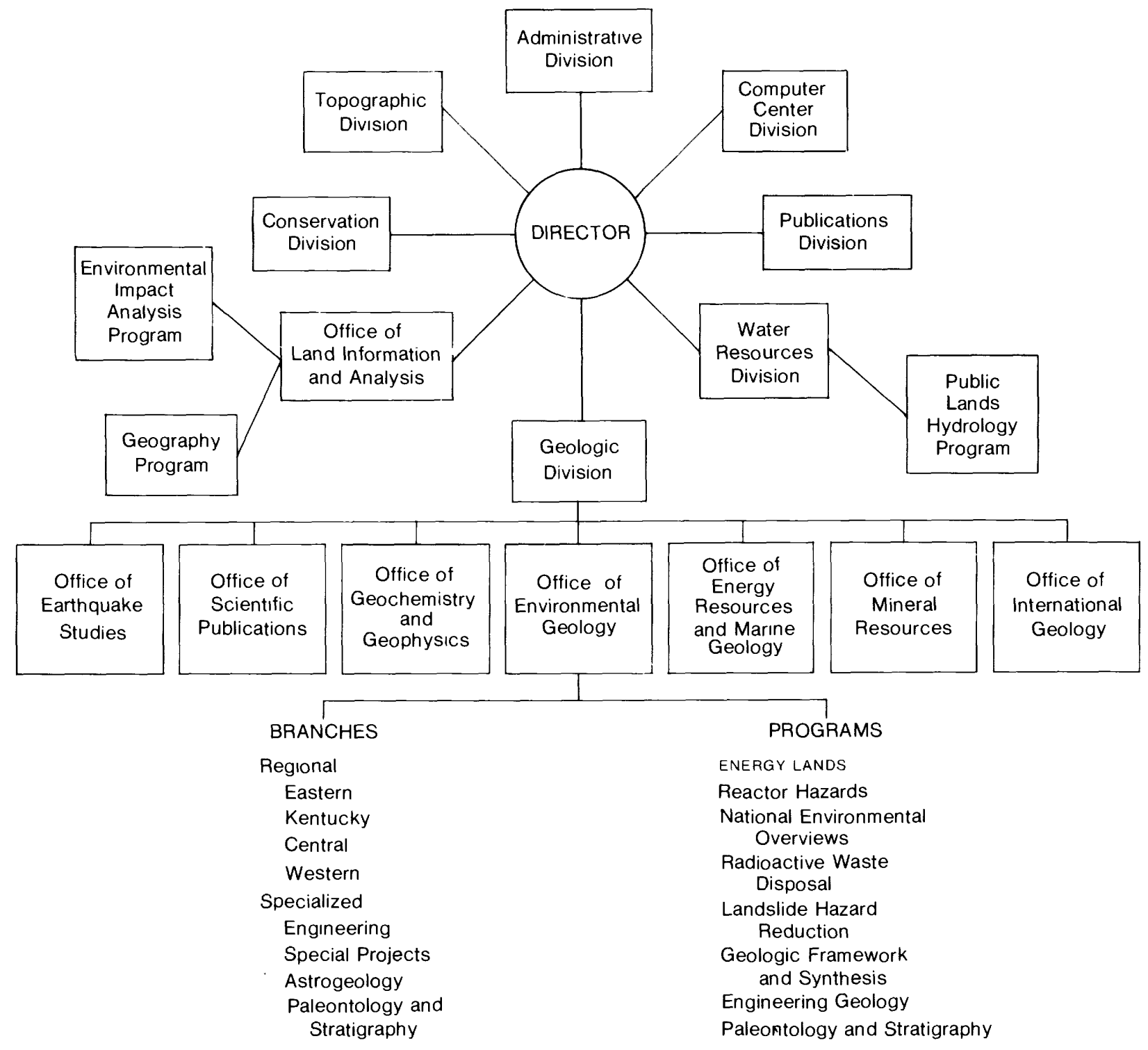

Figure 1.--Structure of the U.S. Geological Survey relative to the Energy Lands Program.

special map products of the United States and certain foreign countries. Water Resources Division is responsible for investigation and assessment of the Nation's ground-water and surface-water resources, and for investigations into scientific aspects of hydrology. This division maintains offices in every state and in several universities and other learning centers, and thus is able to keep in close touch with local and state concerns.

The Geologic Division, under the direction of Dallas B. Peck, Chief Geologist, conducts geologic investigations in the United States and certain foreign countries. It is made up of six operating offices (Environmental Geology,
Mineral Resources, Geochemistry and Geophysics, Energy Resources and Marine Geology, Earthquake Studies, and International Geology) and the support office of Scientific Publications.

The Chief of the Office of Environmental Geology, John C, Reed, Jr., directs wide-ranging geologic investigations consisting of such activities as regional geologic mapping, paleontology and stratigraphy, engineering geology, volcanic-hazards research, energy lands research, reactor-hazards research, environmental overview mapping, landslide-hazardreduction research, radioactive waste disposal, environmental impact analysis, climate change, urban geology, and nuclear reactor site investigations. 
The office Chief and his immediate staff are aided in the direction of office activities by Branch Chiefs and Program Managers who coordinate and cooperatively supervise the progress of projects. The office of Environmental Geology is made up of four regional branches (Eastern, Kentucky, Central and Western) and four specialized branches (Engineering Geology, Special Projects, Astrogeology, Paleontology and Stratigraphy). Both Engineering Geology and Paleontology and Stratigraphy, because of the specialized nature of their basic work, are also designated as programs. The remainder of the programs are Geologic Framework and Synthesis, Energy Lands, Reactor Hazards, National Environmental Overviews, Landslide Hazard Reduction, and Radioactive Waste Management.

of extreme importance to the successful implementation of the mission of the Energy Lands Program is cooperation with the Offices of Energy Resources and Geochemistry and Geophysics, the Public Lands Hydrology Program of the Water Resources Division, and the Geography Program and Environmental Impact Analysis Program of the Office of Land Information and Analysis, Without the cooperation of these elements, the Energy Lands Program could not exist.

\section{PROGRAM OBJECTIVES}

The objectives of the Energy Lands Program are to assist in the analysis and solution of environmental problems associated with energyresource extraction and utilization and the planning, siting, and construction of energy conversion and distribution facilities. This is accomplished through the acquisition, interpretation, and dissemination of geologic, hydrologic, geochemical, and related information. Considerable emphasis is placed on the communication of technical and scientific information in a manner that is readily understood and of direct use to those who are responsible for formulating policies and rendering decisions that affect energy-resource development, but who are not specifically trained in earth science, Results and findings of the investigations are published as written reports and folios of maps showing basic data and derived and interpreted data.

The program is designed to assist in planning safe, orderly, and efficient development of the Nation's energy resources with minimum impact on the environment. To this end, investigations include the environmental geologic aspects of accelerated development and production of solid fossil fuels. These studies are designed to evaluate and minimize hazards and adverse impacts of extraction, processing, conversion, and transportation of energy resources and of urbanization related to energyresource development. Work is concentrated in the Western United States because there are extensive tracts underlain by thick surfaceminable oil shale and coal deposits, rapid development on a very large scale is imminent, and the environmental setting is complicated and is largely not well understood. Complex surface and subsurface ownership involves extensive Federal, State, and private interests that require major Federal legislation and policy decisions that undoubtedly will be tested in the courts. Most Energy Lands studies emphasize regional environmental analysis with special emphasis on mapping and active geomorphic processes, in an effort to provide reliable earth science information useful in these and other issues.

\section{PROGRAM PROJECT DETAILS}

In the project descriptions that follow, all project Chiefs are based in Denver at the following address, unless otherwise noted: U.S. Geological Survey, Box 25046, Federal Center, Lakewood, co 80225. Reports published in Fiscal Year 1976 are 1isted for each project instead of in a bibliography at the end of the report.

USGS In-House Projects

Project Number/Name: 9530-01931

Program Manager, Energy Lands Program

Branch: Office of Environmental Geology

Project Chief: J, o, Maberry, Denver (303-234-4857)

Total Project Area: Nationwide in energy lands

Objectives:

Major objectives are to coordinate and participate in the collection, assessment, and interpretation of earth science information on environmental aspects of energy resource recovery, transportation, and utilization; to direct and conduct basic bedrock, surficial, and engineering geologic investigations; and to coordinate the design and scheduling of the Program's interpretive and derivative program reports with individuals and organizations charged with carrying out all implications of the Nation's energy policies, at local, State, and National levels. Further objectives are to help program scientists to present their results in broadly understandable formats.

Progress in FY 76 :

New project FY 77; previous Program Manager was Project Chief of Eastern Powder River Basin Investigations (9530-01565). 
Products in FY 76:

Grants and contracts to State Geological Surveys and universities.

Work in progress in FY 77:

Compilation of administrative reports; review of folios of program reports; encouraging requests and making new grants to State Surveys and universities.

Project Number/Name: 9510-01927

Carbonates for $\mathrm{SO}_{2}$ Scrubbing

Branch: Eastern Environmental Geology

Project Chief: J. B. Epstein, USGS National Center, Reston, VA 22092 (703-860-6409)

Total Project Area: Nationwide (fig, 2).

Objectives:

The objectives of this project are to identify, through literature research and consultation with appropriate authorities, those carbonate rock types most suitable for scrubbing $\mathrm{SO}_{2}$ emissions in flue gases from coal-fired generating plants. A generalized map of the United States (scale 1:7,500,000) will be prepared showing the distribution of those rock types. A summary report will describe the relationship of carbonate reactivity to chemical and physical properties of the rocks, the existing technology of the scrubbing process, and engineering and environmental problems related to the scrubbing process. A study of the economics of transporting carbonates having different reactivities and other properties over varying distances will be initiated. Followup research, such as problems of waste and sludge disposal and utilization, will be identified for possible future efforts by USGS. Areas deserving more detailed map compilation and subjects for topical studies will be identified for future work. The map to be prepared for this project will be coordinated with a series of maps being prepared or proposed by the National Environmental overview Program; it will be one element in a national assessment of geoenvironmental characteristics of coal extraction.

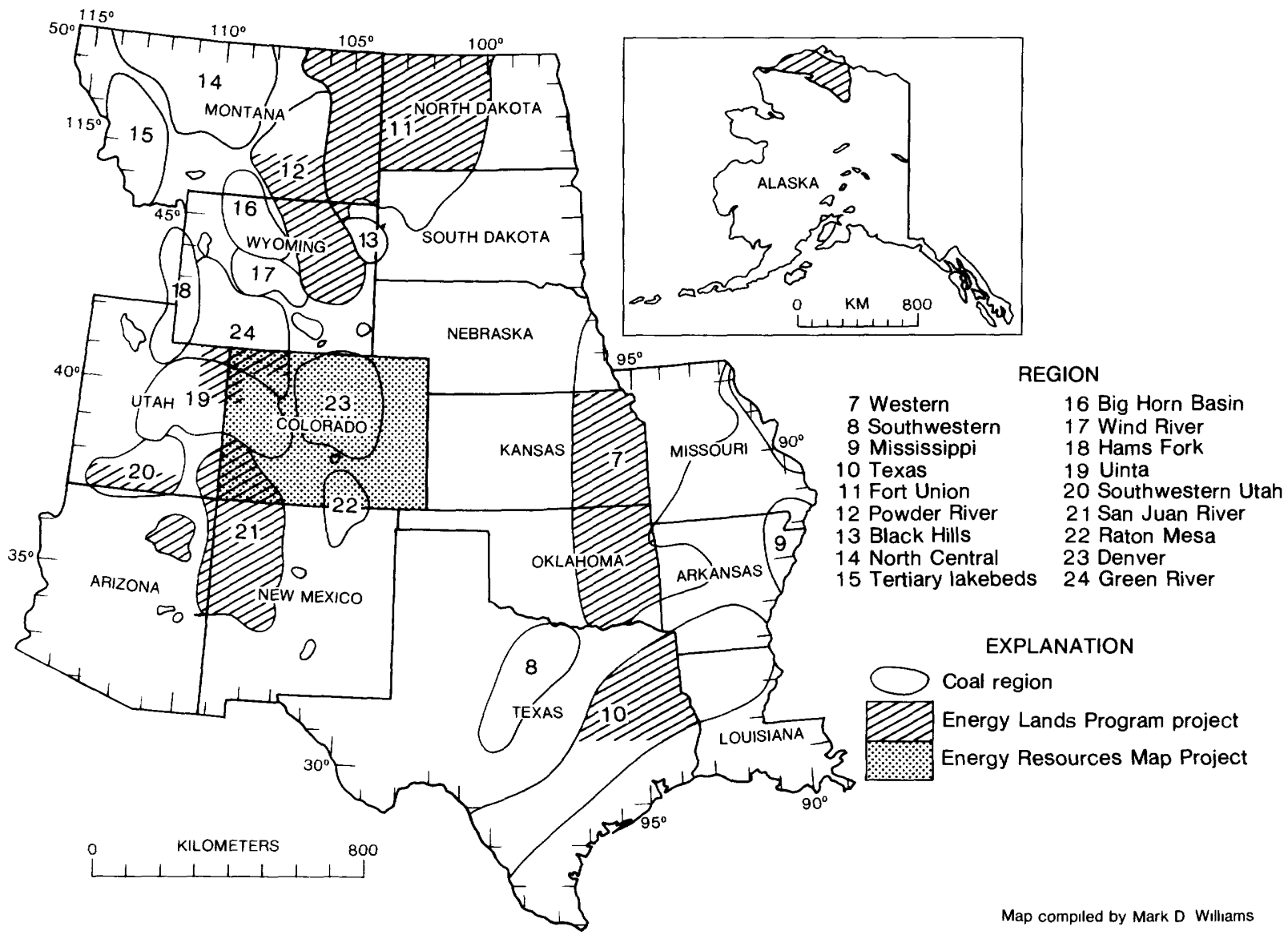

Figure 2.--Maps of Western Interior of the United States and of Alaska showing coal regions and location of Energy Lands Program projects. 
Progress in FY 76: New project FY 77

Reports in FY 76: None

Work in progress in FY 77:

Investigating the existing technology of scrubbing processes, and compiling a map showing distribution of various carbonate rock types in the United States.

Planned changes in FY 77:

Proposal for more detailed maps and topical studies for post-FY 77 .

Project Number/Name: 9530-01552

Black Mesa Basin, Arizona

Branch: Central Environmental Geology and Astrogeology Branches

Project Chief: T, N. V. Karlstrom, USGS Center, 2255 North Gemini Drive, Flagstaff, AZ 86001

Total Project Area: lat $35^{\circ} 30^{\prime}-37^{\circ}$ N.; long $109^{\circ}-111^{\circ}$ W.; 75,000 $\mathrm{km}^{2}$ (Arizona) (fig. 2).

Objectives:

The objectives of this project are to map in detail the surficial geology of the region, using remote sensing and conventional field procedures; and to conduct experiments using computer-enhanced satellite photographs as base maps in order to evaluate the use of telegeology for rapid regional mapping of surficial geology and for geoenvironmental analysis. Further objectives are to reconstruct the erosional, depositional, and vegetational history of the region to aid in constructing baselines against which to measure future reclamation efforts. This is accomplished through detailed analysis of alluvial, colluvial, and eolian sediments containing ${ }^{14} \mathrm{C}$ and other datable materials. The project is designed to resolve, as precisely as possible, the pattern of past changes in the rates of geologic processes and in the physical environment of the region as a means for assessing the impacts of modern man's activities, including largescale mining operations, on the current and future environmental quality.

Progress in FY 76:

Field observations and measurements were made, and samples were collected for analysis. Photogeologic compilation was in progress for the entire area; a natural vegetation map was in progress. A detailed Holocene stratigraphic section was compiled, keyed to different heights and numbers of alluvial terraces, to deduce the depositional and erosional history of the area. Surficial geologic mapping in the region has revealed a systematic pattern of past hydrologic and climatic changes (Karlstrom and others, 1974; Hevly and Karlstrom, 1974) that have repeatedly affected agricultural potential; prehistoric cultures; and the rates and frequencies of erosion, alluvial and eolian deposition, and landsliding. Projection of this pattern into the future indicates that the present drier climate and arroyo cutting may shift in the next few decades towards a wetter climate and general aggradation of arroyo floors. These geologically derived insights into the magnitude and frequency of past natural environmental shifts help provide an objective base for evaluating the current and possible future effects of surface-mining operations in a marginal southwest desert environment.

Reports in FY 76 :

Sutton, R. L., Pleistocene and Pliocene deposits in the Hopi Buttes area, southern Black Mesa Basin, Arizona: Am. Assoc. Adv. Science Ann. Mtg, Abs, with Programs, (in press).

Hereford, R, E,, 1977, Deposition of the Tapeats Sandstone (Cambrian) in central Arizona: Geol. Soc. America Bull., v. 88, no. 2, p. 199-211.

Karlstrom, T. N. V., Gumerman, George, and Euler, R. C., 1975, Paleoenvironmental and cultural changes in the Black Mesa Region, northeastern Arizona, in Horie, S., ed., Paleolimnology of Lake Biwa and the Japanese Pleistocene, Volume 3: Kyoto, Japan, p. 494-517.

Helvy, R. H., and Karlstrom, T. N. V., 1975, Southwest paleoclimate and continental correlations, in Horie, $\mathrm{S}$., ed., Paleolimnology of Lake Biwa and the Japanese Pleistocene, V. 3: Kyoto, Japan, P. 455-493.

Work in progress in FY 77:

Specific investigations in FY 77 include engineering materials of the Black Mesa Region; studies of Colorado Plateau prehistoric cultures and changing geologic environments; buried forests and the alluvial record of the southwest; climate, geomagnetism, and volcanic history; statistical analysis of paleoclimatic time-series; development of the landscape of northeastern Arizona; and Quaternary and Tertiary timestratigraphy of the Colorado Plateaus, continental correlations, and paleoclimatic complications.

Planned changes in FY 77:

Shift in emphasis from regional stratigraphic to topical energy-related studies; shift in 
priorities from bedrock geology (already existing) to interpretive and derivative maps and reports pertinent to environmental geologic aspects of strip mining at Black Mesa.

Project Number/Name: 9530-01560 Geologic Factors for Mapping Reclamation Potential of Western Coal Lands

Branch: Central Environmental Geology

Project Chief: H. E. Malde, Denver (303-2342864)

Total Project Area: Selected areas (fig. 2, areas $12,19,21$ ).

Objectives:

The project objectives are to determine the major geologic factors that influence reclamation of surface-mined lands in regions of strippable coal in the western United States, and to determine a quantitative geomorphologic assessment of selected lands in differing physical environments, To this end, project scientists compile maps, diagrams, and photographic records showing differing degrees of potential for reclamation based on differences in geologic factors.

\section{Progress in FY 76 :}

The reclamation potential for surface-mined lands was evaluated and mapped for areas underlain by strippable coal near Gillette, Wyo. The evaluation of potential for reclamation was based on 8-hectare parcels of land, and is classed as potentially good, fair, or poor. The map shows the likelihood of returning the environment to a set of desired physical conditions after surface mining, and is designed to be used for resource management in areas of planned surface mining. The map shows specific sites for which stipulations written into the mine plan might be considered in order to reduce environmental disturbance.

A composite-mapping system that uses a computer was adopted to evaluate reclamation potential. Using this system, the reclamation potential of a variety of environmental factors was combined to obtain the overall reclamation potential. The definition of realistic standards of reclamation for six major environmental factors and assessment of their likelihood of successful implementation required compilation of much field data and other information from reclamation research. The final map was a composite of 16 factor-source maps. The method has high transfer values and can be used in other regions having sufficient environmental baseline data.
The method also has been used to evaluate the natural variability of premining natural resources in areas of impending resource development. This provides a method of evaluating previously unquantified resource values such as scenic values and recreation desirability. A map of environmental values was made for The Gap 7 1/2-minute quadrangle south of Gillette.

Alluvial valley floors were mapped in areas of proposed and active surface coal mining in North Dakota, Montana, Wyoming, Colorado, and New Mexico in order to provide data requested by the House Subcommittee on Mines and Mining of the U,S. Congress.

Additional stations for observation of landscape change were established in Chaco Wash, N, Mex., and sites of historical photographs were rephotographed.

Reports in FY 76:

Malde, H, E., and Boyles, J, M., 1975, Maps of alluvial valley floors and strippable coal in forty-two 7 1/2-minute quadrangles, Big Horn, Rosebud, and Powder River Counties, southeast Montana: U.S. Geol. Survey Open-File Report 76-162.

Malde, H. E., [1975], Reclamation of mined land, in Kennedy, W. J. D., ed., and others, Coal in the West--The reclamation question: Rocky Mountain Center on Environment and Federation of Rocky Mountain States, Summit on Coal, Conf,, Denver, $1975,18 \mathrm{p}$.

Moore, D. W., and Boyles, J. M., 1976, A map of environmental values as an aid to planning reclamation of surface-mined areas--The Gap quadrangle, Wyoming: U.S. Geol. Survey Open-File Report 76-434.

Moore, D. W., 1976, A method of mapping reclamation potential for an area of strippable coal in northeastern Wyoming: Geol. Soc. America Abs, with Programs, v. 8, no. 7, p. 1016 .

Work in progress in FY 77:

Investigations into diverse aspects of the potential for reclamation of surface-mined lands, including observations of contemporary arroyo cutting near Santa Fe, N. Mex.; further refinements in the technique of reclamation-potential mapping in semiarid regions of strippable coal, and of evaluating and mapping environmental resources.

Planned changes in FY 77: None

Project Number/Name: 9530-01565

Environmental Aspects of Coal Development, Eastern Powder River Basin 
Branch: Central Environmental Geology

Project Chief: D. A. Coates, Denver (303-234-5260)

Total Project Area: lat $43^{\circ} 30^{\prime}-45^{\circ} 00^{\prime} \mathrm{N}$, long $105^{\circ}-106^{\circ}$ W.; $6,100 \mathrm{~km}^{2}$ (Wyoming) (fig, 2, region 12 ).

Objectives:

The major objectives are to acquire, compile, and interpret environmental geologic aspects of basic information on coal resources and on materials and processes of the land surface. This information will be used for evaluating the environmental resources of the coal area of Campbell County, Wyo.; for identifying potential environmental problems in the accelerated development of coal mining and associated industries; and for assisting concerned groups at the local, State, and National levels in recognizing the problems, in determining solutions, and in rational planning of land use and resource management.

Progress Progress in FY 76:

The surficial geology in all or parts of thirty 7 1/2-minute quadrangles in the strippable coal zone that extends the length of Campbell County, Wyo., was mapped in FY 76. The necessary field studies in the total of forty-six 7 1/2-minute quadrangles and half of each of two 15-minute quadrangles in the project area will continue in FY 77 . Photointerpretation to complete the maps will continue. About 20 different surficial geologic units are delineated on these maps. The information provided on these maps is fundamental to land-use planning, siting of construction, and evaluating environmental impacts. In addition, soil scientists, geochemists, and bedrock geologists have requested this information to assist in their work.

Derivative maps begun in FY 76 show geologic hazards and constraints to development or land use. Factors shown include potentially unstable slopes, flood-prone areas, areas of difficult access, areas of strippable coal, areas underlain by potential sources of aggregate, and areas containing hard rock near the surface. These maps will be made for selected quadrangles in which the most development is expected. Although the maps provide explicit, easily read information on possible hazards and limitations, they do not replace detailed inspection of a given site if development is proposed.

Simulated post-mining terrain maps were begun in FY 76 for a tract of land $30 \mathrm{~km}$ long that is underlain by strippable coal of the Wyodak-Anderson coal deposit. These maps, at the scale 1:24,000 and with a contour interval of $20 \mathrm{ft}$, depict the land surface as it would be if mining were to be carried out using certain standard mining methods that are defined in the map explanation. Advance knowledge of the potential landscape modification is necessary to produce mining plans that will minimize adverse physiographic and hydrologic changes in the most economical way. Potential adverse effects of mining in this region include extensive areas of internal drainage and disrupted flow of through streams,

Studies underway on alluvial valley floors show that the history of alluvial cutting and filling is more complex than was previously understood. Further information on the chronology and processes involved in this cutting and filling may help in predicting the consequences of large-scale mining on the stream valleys.

Project personnel are assisting in the preparation of maps showing coal resources in southern Campbell Gounty, This is a continuing cooperative project with $\mathrm{N}$. M. Denson (Uranium and Thorium Branch, Geologic Division) to correlate and evaluate coal resources throughout the Powder River Basin.

Reports in in FY 76:

Coates, D. A., Williams, V. S., and Fullerton, D, S., 1976, Surficial geology mapping in the eastern Powder River Basin, Wyoming--A progress report: Geol. Soc., America Abs. with Programs, v. 8, no, 5, p. 577-578.

Keefer, W. R., and Hadley, R. F., 1976, Land and natural resource information and some potential environmental effects of surface mining of coal in the Gillette area, Wyoming: U.S. Geol. Survey Circ. 743, 27 p.

Work in progress in FY 77:

Investigations include surficial geologic mapping in the following 7 1/2-minute quadrangles, Wyoming: Larey Draw, Spotted Horse, Croton, Truman Draw, Moyer Springs, Green Hill, Gillette East, Fortin Draw, Appe1 Butte, The Gap, Coyote Draw, Coon Track Creek, Scaper Reservoir, The Gap SW, Saddlehorse, White Tail Creek, Rough Creek, Highlight, Open A Ranch, Reno Reservoir, Piney Canyon NW, Teckla, Piney Canyon SW. Further research is being conducted into usefulness of maps at different scales and the feasibility of compilation of data at small scales.

Planned changes in FY 77: None

Project: Geochemical Survey of the Western Energy Regions 
Organizational Designation: Geologic Division, Office of Geochemistry and Geophysics, Branch of Regional Geochemistry

Project Chiefs:

R. J. Ebens (rocks), Denver (303-234-2924)

R. R. Tidball (soils), Denver (303-234-4244)

J. A. Erdman (vegetation), Denver (303234-5240)

G. L, Feder (waters), Denver (303-234-2404)

W. E. Dean (oil shale), Denver (303-234-2310)

Total Project Area: Western United States (fig, 2).

Project Status and Plans:

The prime objective of the work is to make a broad-scaled reconnaissance geochemical survey of the landscape of the Western Energy Regions with a view to establishing provisional geochemical baselines for immediate use and setting up cost-effective guidelines for future sampling aimed at more detailed baselines. The original focus of the work was on the coal-bearing lands of the West, and the primary interest remains there; but field studies have been expanded to include the oil shale region of Colorado, Utah, and Wyoming, and a preliminary assessment has been made of the geochemical impact of uranium mining and milling on the trace-element character of the local landscape.

\section{Progress in FY 76:}

The work is directed at describing the geochemistry, particularly the trace-element geochemistry, of the rocks, soils, plants, and waters of the major energy-bearing regions of the Western United States. Work to date has been directed primarily to the northern Great Plains, including the Powder River Basin (fig 2, region 12) and the oil shale region; but field collections also have been made throughout the Big Horn and Wind River Basins of Wyoming and adjacent to four coal-fired powerplants (Colstrip, MT; Dave Johnston, WY; Jim Bridger, WY; and Four Corners, NM), as well as from scattered sites of investigations by the EMRIA Program of the Bureau of Land Management. Plans for fieldwork in the immediate future are aimed at the more southern coal-bearing areas in Utah, Colorado, New Mexico, and Arizona, with greatest emphasis directed to the San Juan Basin.

Reports in FY 76:

U.S. Geological Survey, 1976, Geochemical survey of the western energy regions--Third annual progress report, July 1976; U.S. Geol. Survey Open-File Report 76-729, 135 p.
Project Number/Name: 9550-01631 Engineering Geologic Studies, Powder River Basin

Branch: Engineering Geology

Project Chief: F. W. Osterwald, Denver (303-234-3818)

Total Project Area: lat $44^{\circ} 07^{\prime} 30^{\prime \prime}-46^{\circ} 00^{\prime} \mathrm{N}$, long, $106^{\circ} 52^{\prime} 30^{\prime \prime}-107^{\circ} 22^{\prime} 30^{\prime \prime}$ W.; $_{10,430 \mathrm{~km}^{2}}$ (Wyoming, Montana) (fig. 2, region 12 ).

\section{Objectives:}

Principal objectives of the project are to provide a better understanding of the behavior of bedrock and surficial geologic materials related to surface and underground coal mining, energy conversion, facility siting, and future urban and industrial growth along the western margin of the Powder River Basin. These highly transferrable data are deduced through studies of stability of cut slopes in strip mines, surface subsidence over abandoned underground coal mines and in areas of burning coal beds, seismic monitoring of strip mines and proposed mine sites, investigation of regional geotechnical properties and associated slope stability processes, engineering geologic mapping of projected urban areas and regional engineering geologic mapping of the northwestern part of the Powder River Basin, engineering geophysical investigations to support geologic mapping and associated geotechnical studies, and geotechnical analysis of drill cores from selected sites.

Progress in FY 76 :

The seismicity of felt earthquakes in the Powder River Basin was compiled on a map of the basin. The area is classed as one of less-than-minor damage. A seismic survey of a landslide near Sheridan, Wyo., disclosed an apparent relation between the slide plane and the base of the weathered zone. Engineering seismic and magnetic surveys of baked and fused rocks (clinker) show that the material has low strength and that buried margins of clinker deposits can be located using magnetic methods. Interpretation of geophysical well logs aimed at correlating physical properties with subsidence of underground openings was begun.

Physical properties of rocks in and near open-pit mines of western Powder River Basin were incorporated into a finite element limit-equilibrium analysis, and the factor of safety was found to be less than one (indicating imminent failure) under some conditions when mining slows or stops. Timedependent nature of the deformation of highwalls is critical. 
On the basis of mining methods used 25 to 50 years ago, it was concluded that open-pit mining has been significantly less damaging to the environment in the western Powder River Basin than underground mining. Based on percent of recovery, open-pit mining is far superior in production of coal. Further, subsequent reclamation of land disturbed by surface mining results in stable ground, whereas unstable and differentially subsiding ground is common above old underground mine workings.

The integrated Tongue River-Goose Creek drainage basin west of Sheridan is marked by extensive pediments and terraces and coincidentally is marked by thinning coal beds that grade westward into carbonaceous shales, The Roland marker coals thin and become lenticular and more carbonaceous in that area, making the boundary between the Paleocene Fort Union and Eocene Wasatch Formations very tenuous.

Five coal zones were delineated in a 133-mdeep core hole drilled at Buffalo, Wyo. Results of geotechnical tests showed the coal units to be the most competent units. Artesian flow from a near surface aquifer of unconsolidated sand must be considered in any coal mining plans.

Mapping of the Buffalo 7-1/2-minute quadrangle was completed. Geologic hazards in and near Buffalo consist of stream flooding from cloudbursts in the Clear Creek drainage basin, local landsliding along the south valley slope of Clear Creek, and surface subsidence resulting from pre-1912 underground coal mining in the southeast part of Buffalo and about $2.4 \mathrm{~km}$ northeast of the town.

Project scientists sampled and instrumented a landslide in the Wasatch Formation $16 \mathrm{~km}$ south of Sheridan, Wyo. Core samples indicate a failure zone less than $7 \mathrm{~m}$ below the surface of the landslide that involves weathered bedrock and colluvium. The transition from disturbed to undisturbed material corresponds both to changes in natural moisture content from generally above to generally below the plastic limit and to an increase of pocket penetrometer indices from $2.5 \mathrm{~kg} / \mathrm{cm}^{2}$ to more than $5.0 \mathrm{~kg} / \mathrm{cm}^{2}$.

Rocks from 250 core samples at Recluse, Wyo. and Bear Creek, Mont. were tested for geotechnical properties; the tests are about 90 percent complete. Tentative conclusions are that most rocks have low compressive and tensile strengths which, with other properties, suggest the need for careful design of mining procedures and careful consideration of geology in mine planning.
Geologists reexamined records of seismic activity at the long-abandoned and burning Acme coal mine near Sheridan, Wyo. In the past 12 months the seismicity related to burning coal in and around the old mine and the subsidence of the ground surface have increased markedly. Both the total number of microseisms and the amplitudes of individual microseisms have increased. These increases apparently are associated with accelerated burning when coal in and near the old mine has ignited spontaneously. Gases emitted from the burning areas contain methane, carbon monoxide, carbon dioxide, carbon oxysulfide, carbon disulfide, and more nitrogen and helium than normal air, and would pose a serious problem to human population if they were released in a populated area.

Reports in FY 76:

Chleborad, A. F., Nichols, T. C., Jr., and Ebaugh, W. F., 1976, A preliminary inventory, profile, and statistical evaluation of landslides in a region of projected urban development, Sheridan, Wyoming: U.S, Geol. Survey open-File Report 76-571, 50 p. 26 figs., 4 tables.

Dunrud, C. R., 1976a, Coal mine subsidence, in Sargent, K. A., and Hansen, D. E., General geology and mineral resources of the coal area of south-central Utah: U.S. Geol. Survey Open-File Report 76-811, p. 83-98 (also Project No. 9550-00644).

1976b, Surface subsidence and coal mine fires, in Trimble, D. E., and others, Summary description of the geologic environment of the Williston Basin lignite fields, North Dakota: U.S. Geol. Survey Adm. Rept., p. 65-68 (for EIS Tech. Support Doc.) (also Project No, 9550-00644).

Ebaugh, W. F., 1976, Preliminary surficial and bedrock geologic map of the Big Horn quadrangle, Sheridan County, Wyoming: U.S. Geol. Survey Misc. Field Studies Map MF801,20 p. text.

Ebaugh, W. F., Chleborad, A. F., and Nichols, T. C., Jr., 1976, Geologic investigation of landsliding in the Big Horn quadrangle, Sheridan County, Wyoming [abs.]: ColoradoWyoming Acad. Sci. Jour, v. 8, no. 1, p. 34.

Fahy, M. P., and Smith, W. K., 1976, Geotechnical properties of some upper Fort Union rocks from the Decker area, Big Horn County, Montana: U.S. Geol, Survey OpenFile Report 76-596, 31 p., 90 figs., 14 tables. 
Farrow, R, A., 1976, Preliminary report on the geotechnical properties of the Wasatch Formation at Buffalo, Wyoming: U,S. Geol. Survey Open-File Report 76-877, 78 p.

Kanizay, S. P., obernyer, S. L., and Catermole, J. M., 1976, Preliminary geologic map of the Buffalo area, northwest Powder River Basin, Wyoming: U.S. Geol. Survey Misc. Field Studies Map MF-806.

Osterwald, F. W., compiler, 1976a, Engineering geologic characteristics, Part B of Summary of the geology, mineral resources, and engineering geologic characteristics of the northern Powder River coal region, Montana: U.S. Geol. Survey Adm. Rept., 51 p. (for EIS Tech. Support Doc,).

1976b, Some engineering geologic characteristics of the Sweetwater-Kemmerer area, Wyoming: U.S. Geol. Survey Adm, Rept., 22 p. (for EIS Tech, Support Doc.).

Osterwald, F. W., and Dunrud, C, R, , 1976, Engineering geologic characteristics of the central Utah coal mining region: U.S. Geol. Survey Adm. Rept., 26 p. (for EIS Tech, Support Doc.).

Work in progress in FY 77:

Investigations include preliminary assessments of natural slope stability in the coal resource area of southwestern Wyoming; mapping of natural slopes in the Big Horn quadrangle, Wyo.; experimentation with a new technique for inclinometer casing installation; and instrumentation studies of highwall stability in surface coal mines of the western Powder River Basin in Wyoming and Montana. Other work in progress includes feasibility studies pertaining to environmental and resource recovery problems associated with past underground coal mining activities in the western part of the Powder River Basin; field studies of seismicity of parts of the western part of the Powder River Basin and assessment of seismic risks; geotechnical and geophysical investigations of clinker deposits; geologic mapping in the Buffalo-Sheridan urban corridor; surface effects of coal mine subsidence in the western Powder River Basin; and investigations into the geotechnical and geophysical properties of the Fort Union Formation.

Planned changes in FY 77: None

Project Number/Name: 9530-01598 Northwest Colorado 0il Shale Environmental Geology

Branch: Central Environmental Geology
Project Chief: R, B, Raup, Denver (303-234-4189)

Total Project Area: 1 at $39^{\circ}-41^{\circ}$ N., long $106^{\circ}-$ $110^{\circ}$ W.; $60,700 \mathrm{~km}^{2}$ (Colorado, Utah) (fig. 2, regions 19,24 ).

Objectives:

Principal objectives are to make bedrock and surficial basic geologic maps $(1: 250,000)$, and derivative and interpretive maps of aspects of environmental geology from basic data. Publication of the maps will be on new county-map bases at 1:50,000 or $1: 100,000$ scale. Land capability maps and reports will be produced to aid persons charged with deciding land use and land restoration following mining. The maps and reports will help in evaluating constraints to land use by industry and individuals. Other objectives are to conduct research into rates of erosion and deposition, landform analysis, and plant distribution as a function of geologic terrane.

\section{Progress in FY 76 :}

detailed bedrock mapping in the Dinosaur National Monument area, Utah and Colorado, continues to confirm that drape folds are the main structural feature in the southeastern Uinta Mountains. Thus, sharp monoclines and asymmetrical folds dominate, but their controlling high-angle faults rarely reach the surface, Landslides in the eastern Uintas also are extremely abundant, especially in areas underlain by the Upper Jurassic Morrison Formation and Upper Cretaceous Mancos Shale; several landslides cover areas that are larger than $20 \mathrm{~km}^{2}$.

Two early man fire pits containing datable charcoal were found at depths of 3.3 and $7.1 \mathrm{~m}$ in the older of two alluvial deposits in the basin of Piceance Creek, northwestern Colorado. According to historic records, present arroyos were cut between the $1880^{\prime} \mathrm{s}$ and 1900, when large herds of cattle and sheep were introduced to the basin. After 1900, the principal activity of the arroyos has been channel widening in the main valleys at rates as fast as $1 \mathrm{~m}$ per year in some isolated areas.

Previous maps of the Vernal $2^{\circ}$ quadrangle showed only a few landslides, Recent fieldwork and airphoto analysis reveal approximately 500 rotational slumps and earthflows in this region that are large enough to be shown on maps at a scale of 1:250,000, other smaller deposits of mass movement such as talus, debris flow, rock avalanches, and soil creep also are abundant in the area. Large areas of eolian sands and numerous gravel terraces occur along the 
Little Snake and Yampa Rivers in northwestern Colorado. Large areas of pediment gravels lie along the south flank of the Uinta Mountains in Utah. Some of these gravels probably are pre-Quaternary in age because they are several hundred meters above present stream levels or because their lithologies are different from those of modern gravels. A humate-rich sample from the base of a bog behind a small moraine approximately $2 \mathrm{~km}$ from the cirque headwall yielded a date of $6,210 \pm 250$ B.P. As this sample consisted of wood fragments and peat, its date provides only a minimum date for the formation of the associated moraine, which probably represents a late-Pinedale standstill.

Abundant fluvial stratigraphy along the five major rivers that drain the Craig $2^{\circ}$ quadrangle (Colorado, Yampa, North Platte, White, and Little Snake) provides the potential for establishing a chronology for Quaternary units and is vital to environmental studies of a variety of geologic processes. Correlation of stream terrace deposits based on their heights above stream level is unreliable; terrace deposits vary both in number and geometry from basin to basin, indicating that individual basins have independent erosional and tectonic histories. (For example, a thin bed of type 0 Pearlette ash $(0.6 \mathrm{~m} . \mathrm{y}$, old $)$ occurs in a terrace deposit $134 \mathrm{~m}$ above the Little Snake River.) The same ash occurs in terrace deposits in the Front Range Urban Corridor of Colorado about $67 \mathrm{~m}$ above stream level of the South Platte River. Hence, it appears that net erosion over the past 600,000 years has been twice as great in the upper Little Snake River drainage as in the upper South Platte drainage. Amino acid dating of two molluscan faunas found beneath Pearlette ash at two localities may provide a calibration applicable to other fauna not associated with ash, which were collected from several other localities in the Yampa drainage basin. Holocene sediments datable by radiocarbon techniques have been obtained at several sites on or near valley floors. Age determinations are in progress on two sets of samples from a dune field south of the Little Snake River. Soil and stratigraphic relations indicate that the dune fields predate "Altithermal" time. The $14 \mathrm{C}$ samples are from a hearth whose associated artifacts suggest an age of about 5,000 yrs B.P., and from a buried paleosol $0.5 \mathrm{~m}$ below the dune surface. Other samples tested for ${ }^{14} \mathrm{C}$ ages are from lake and bog deposits near Buffalo Pass in the Park Range and in the Never Summer Range. Analysis of the diatom record at the Never Summer Range site was carried on in FY 76 and extends into FY 77 . The ${ }^{14} \mathrm{C}$ ages and paleontology will supply information about time of deglaciation and postglacial history, information useful in evaluating peat as a resource.

Reports in FY 76:

Carrara, P. E., 1976, Erosion rates from exposed tree roots, Piceance Creek area, Colorado [abs]: Fourth Biennial Meeting of the American Quaternary Assoc., Tempe, Arizona, p. 131.

Hansen, W. R., Geologic map of the Canyon of Lodore south quadrangle, Moffat County, Colorado: U.S. Geol. Survey Geol, Quad. Map GQ-1403.

, Geologic map of the Zenobia Peak quadrangle, Moffat County, Colorado: U.S. Geo1. Survey Geo1. Quad. Map GQ-1408.

Geologic map of the Jones Hole quadrangle, Uintah County, Utah, and Moffat County, Colorado: U.S. Geol. Survey Geol. Quad. Map GQ-1401.

Pipiringos, G. N., Geologic map of the White Peak quadrangle, Moffat and Rio Blanco Counties, Colorado: U.S, Geol. Survey Misc. Field Studies Map MF-837.

Geologic map of the Indian Valley quadrangle, Moffat and Rio Blanco Counties, Colorado: U.S, Geol. Survey Geol. Misc. Field Studies Map MF-836

Work in progress in FY 77:

Investigations include geologic mapping in the Indian Water Canyon quadrangle, Moffat County, Colo.; surficial geologic mapping in the Grand Junction, Craig, and Vernal $2^{\circ}$ areas; studies of Quaternary stratigraphy along the Little Snake River near Baggs, Wyo,; soil stratigraphy of glacial deposits in the upper Canadian River, Jackson County, Colo.; and detailed studies of the alluvial and erosional history of the Piceance Basin.

Planned changes in FY 77:

Focus of project will be changed somewhat--in view of lessened private, corporate, and governmental interest in oil shale-to provide environmental geologic data pertinent to coal surface and underground mining, as well as to compile information for future oil shale utilization.

Project Number/Name: 9530-01637

Kaiparowits Coal Basin Environmental Geology

Branch: Central Environmental Geology

Project Chief: K. A. Sargent, Denver (303-234-5368) 
Total Project Area: lat $37^{\circ}-38^{\circ}$ N., long $111^{\circ}-$ $112^{\circ}$ W.; $9,900 \mathrm{~km}^{2}$; region 20 (Utah) (fig. 2).

Objectives:

Objectives of the project are to acquire, compile, interpret, and publish basic land and coal resource data in order to evaluate potential environmental impacts related to future Kaiparowits coal development and related activities for land-use planners and decision-makers.

\section{Progress in FY 76:}

Fifty percent of the geology of the project area was compiled at $1: 125,000$ scale from published 1:24,000- and 1:48,000-scale maps. An additional 35 percent was compiled from preliminary geologic maps prepared by scientists in Conservation Division and from unpublished maps.

Three maps have been completed on the hydrology of the Kaiparowits coal basin area: chemical quality of ground water; general availability of ground water; and principal drainage basins, mean annual runoff, and selected streamflow data. These maps should be of great value to land-use planners and to future coal developers in determining sources of domestic-potable, industrial, and generaluse water.

Three coal maps were nearly completed: distribution and thickness of coal, thickness of overburden over the Alvey coal zone, and thickness of overburden over the Christensen coal zone. These maps are for general overview use, and, when coordinated with other maps in the series, should be useful in developmental planning, such as for transportation and communication routes and townsites.

The first draft of a terrain analysis map emphasized the well-known fact that access and transportation in the Kaiparowits area are difficult. Clarification of existing map units and the addition of local geomorphic units are still needed.

Reports in FY 76:

Sargent, K. A., and Hansen, D. E., 1976, General geology and mineral resources of the coal area of south-central Utah, with sections on Landslide hazards by $R$. B. Colton, Coal mine subsidence by C. R. Dunrud, and Landscape geochemistry by J. J. Connor: U.S. Geol. Survey Open-File Report 76-811, 122 p., 24 figs., 4 pl., 12 tables.
Price, Donald, Map showing general chemical quality of ground water in the Kaiparowits coal basin area, Utah: U.S. Geol. Survey Misc. Investigations Map I-1033-A, in press.

Map showing general availability of ground water in the Kaiparowits coal basin area, Utah: U.S, Geol. Survey Misc. InvMap I-1033-B, in press.

Map showing principal drainage basins, mean annual runoff, and selected streamflow data in the Kaiparowits coal basin area, Utah: U.S. Geol. Survey Misc. Investigations Map I-1033-E, in press.

Work in progress in FY 77:

Investigations include mapping of the general chemical quality of surface water; distribution and thickness of the coal; thickness of overburden on coal beds in the Alvey zone; thickness of overburden on coal beds in the Christensen and Henderson coal zones; and mapping of geology, terrain analysis, and scenic and recreational features.

Planned changes in FY 77: None

Project Number/Name: 9530-01932

Environmental Geology, San Juan Basin Energy Lands

Branch: Central Environmental Geology

Project Chief: G. R. Scott, Denver (303-234-3545)

Total Project Area: lat $35^{\circ}-38^{\circ}$ N., long $106^{\circ}$ $109^{\circ}$ W.; $50,000 \mathrm{~km}^{2}$ (New Mexico, Colorado Region 21, fig. 2)

Objectives:

Project geologists will compile existing bedrock geologic mapping at 1:250,000 scale from published information and work in progress in the Cortez area of the San Juan Basin in parts of the Durango, Shiprock, Aztec, Gallup, and Albuquerque quadrangles. Reconnaissance mapping of surficial deposits will be carried out. A 1:250,000-scale map of the San Juan Basin within the area underlain by coal will be compiled from reconnaissance results and from existing information. All surficial deposits will be mapped in detail, and existing geologic maps will be used to compile the bedrock contacts at 1:48,000 scale for the parts of the San Juan Basin underlain by strippable coal deposits as a basis for predicting regional environmental effects of strip mining. Engineering geologic aspects of certain potentially troublesome units. will be investigated and evaluated. 
Other objectives are to interpret basic land and resource data to evaluate the potential environmental impacts of extensive surface mining of coal and to provide bases for geologic assessment of sites for energy conversion and transportation facilities.

Environmental studies will be coordinated with work of other branches of Geologic Division (Coal Resources and Regional Geochemistry) and other Divisions (Water Resources and Conservation) of USGS, as well as with the New Mexico Bureau of Mines and Mineral Resources, in order to achieve a comprehensive knowledge of regional environmental problems. Results of the studies will be regularly communicated to planners and decision-makers.

Progress in FY 76: New project FY 77

Reports in FY 76: None

Work in progress in FY 77:

Geologic and environmental mapping and other investigations, as described above, will make up all work in progress in FY 77.

Planned changes in FY 77: None

Project Number/Name: 9530-01933

Environmental Geology of Eastern MontanaWestern North Dakota Coal Lands

Branch: Central Environmental Geology

Project Chief: D. E. Trimble, Denver (303-234-2825)

Total Project Area: lat $45^{\circ}-49^{\circ}$ N., long $100^{\circ}$ $107^{\circ}$ W.; $100,000 \mathrm{~km}^{2}$ (Montana, North Dakota) (fig. 2, region 11 ).

Objectives:

Objectives are to provide small-scale geologic baseline data relevant to projected development of the lignite and subbituminous coal resources of the Williston Basin in Montana and North Dakota. Geologic hazards maps will be made and will include areas of present and potential landslide hazard and surface-subsidence hazard and geomorphological terrain studies. Maps showing areas of nonmetallic mineral occurrence will be compiled from existing data. Coordination will be effected with appropriate State Geological Surveys and other organizations.

Progress in FY 76:

Project Chief headed a team of geologists who produced a summary report on the geologic environment of the lignite fields of the
Williston Basin for inclusion in the regional EIS (Environmental Impact Statement-currently in preparation).

Reports in FY 76:

Trimble, D. E., Team Leader: Summary description of the geologic environment of the Williston Basin Lignite Fields, North Dakota: US Geol. Survey Open-file report in preparation.

Work in progress in FY 77:

Surficial geologic maps are being compiled from a large amount of existing data. The maps are at a scale of 1:100,000 in order to provide input to USGS map folios as part of the Survey's coal exploration plan. Original mapping will be done to fill holes in existing information, and field checking of completed maps will be carried out. Maps showing geologic hazards and geologic constraints to development will be started.

Planned changes in FY 77: None

Project Number/Name: 9550-01889

Environmental Geology of Alaska Coal Lands

Branch: Engineering Geology

Project Chief: H. R. Schmoll, Denver (303-234-2999)

Total Project Area: Portions of 1 at $55^{\circ}-70^{\circ} \mathrm{N}$., long $141^{\circ}-166^{\circ}$ W.; $500,000 \mathrm{~km}^{2}$ (Alaska) (fig. 2).

Objectives:

Principal objectives are to provide an understanding of the nature, location, and extent of general environmental concerns and potential problems caused by response of geologic materials, both surficial deposits and bedrock, to surface and underground coal mining, energy conversion, facility siting, and accompanying land utilization for associated development (including transportation routes and urban development) throughout Alaska. The project has two phases: an overview to delineate all areas of the state in which reasonable potential for coal mining activity or intense exploration exists and to outline in general terms the environmental-geologic aspects of each, and more detailed studies to be undertaken in selected areas most likely to be sites of major development in the foreseeable future.

Progress in FY 76: New project FY 77

Reports in FY 76: None 
Work in progress in FY 77:

Investigations include literature research, coordination with field parties of other USGS groups, coordination with Alaska Geological Survey personnel, and mapping of environmental geologic aspects of energyresource recovery.

Planned changes in FY 77: None

Project Number/Name: 9540-01591 Geologic Aspects of off-Road Vehicle Use in Desert Areas, U.S.A.

Branch: Western Environmental Geology

Project Chief: H. G. Wilshire, USGS Center, 345 Middlefield Road, Menlo Park, CA 94025 (415-323-2214)

Total Project Area: San Juan Basin, New Mexico (fig, 2. region 21).

Objectives:

This project is designed to determine the amount of soil destabilization and amounts of resulting erosion as a consequence of the use of off-road vehicles in fragile desert environments. The Energy Lands Program part of the project will focus on environmental problems in using unpaved haulage roads and the use of different vehicles on those roads over different geologic terranes in various coal strip-mining areas in New Mexico and Arizona.

Progress in FY 76: New project FY 77

Reports in FY 76: None

Work in progress in FY 77:

Literature research and field investigations are the only work presently taking place.

Planned changes in FY 77: None

\section{Grants and Contracts}

The Energy Lands Program disbursed 10 percent of its appropriations each year in Fiscal Years 1975 and 1976 in the form of grants and contracts. In Fiscal Year 1977, some grants have been completed and some have been renewed. New proposals for grants to fund energy-related environmental geologic studies have been submitted by various State Geological Surveys and universities. To date, the program has granted funds to the Texas Bureau of Economic Geology, Oklahoma Geological Survey, University of Denver, Kansas State Geological Survey, University of Wyoming, and Colorado Geological Survey. One contract was let to a consulting mining engineer for coal mining studies.
Program Grant and Contract Details

Grant Number/Name: $14-08-0001-G-158$ and -316

Land Resources and Environmental Impact--East Texas Lignite Belt

Grantee: Texas Bureau of Economic Geology, Box $\mathrm{X}$, University Station, Austin, TX 78712. Principal Investigator: E. G. Wermund.

Project Area: Parts of Navarro, Freestone, Limestone, Leon, Falls, Robertson, Milam, Williamson, Burleson, Lee, and Bastrop Counties, and the lignite-bearing region of northeast Texas (fig, 2).

Objectives:

Objectives of the study are to assess effects on the physical environment resulting from development of Texas' lignite resources, and to map and report on such effects in a timely manner so as to contribute to orderly development.

Progress through FY 76:

The Eocene Calvert Bluff Formation of Sharp (1966) was recognized as the major lignitebearing unit; active and proposed strip mines were located and plotted on maps; aquifers in the Simsboro Formation of Sharp (1966) and Carrizo Sand were recognized as the aquifers most likely to receive mine runoff.

Twelve mappable land resource units were identified and mapped; baseline ground- and surface-water chemistry of the lignite area was compiled as a baseline for the evaluation of pollution; bibliographies of the geology and hydrology of the lignite belt were compiled; the major floral assemblage of varied substrate units was identified, as well as the floral assemblage that first occupies unreconstructed mine spoil.

Environmental geologic maps were made for the Wilcox Group and Carrizo Sand outcrop belt between the Trinity River and the TexasLouisiana border; lignite potential of a test unit of the Jackson and Yegua Formations (Eocene) was mapped in Madison County; traceelement chemistry of algae from streams in the lignite belt was determined and land use was mapped in vicinities of active strip mines.

Reports through FY 76:

Henry, C. D., 1976, Land-resources inventory of lignite strip mining areas, east Texas-An application of environmental geology: Texas Univ., Bur. Econ, Geology Geol. Circ. $76-2,29 \mathrm{p}$. 
Henry, C. D., Kaiser, W. R., and Groat, C. G., 1976, Reclamation at Big Brown steam electric station near Fairfield, Texas-Geologic and hydrologic setting: Texas Univ., Bur. Econ. Geology Research Note 3, $10 \mathrm{p}$.

Henry, C. D., and Kastning, E. H., 1975, Toward evaluating the potential environmental impact of lignite strip mining in east Texas: Geol. Soc. America Abs. with Programs, v. 7, no. 7, p. 1110.

1976, Environmental geology of the East Texas Lignite Belt: in Kaiser, W. R., ed., Geology, utilization, and environmental aspects: Gulf Coast Lignite Conf. Proc., p. 11 .

Holm, Melody,, 1975, A preliminary study of biologic assemblages of East Texas Lignite Be1t: Texas Univ., Bur. Econ. Geology Research Rept. 1, 23 p.

Seagle, Shirley, 1976, A preliminary study of aquatic plants in the vicinity of the Alcoa aluminum plant and Big Brown generating plant: Texas Univ., Bur, Econ. Geology Research. Note 18, 20 p.

Work in progress in FY 77:

Progress toward successful completion of work under the grant includes compilation of a base map of the lignite area at 1:125,000, sampling and measurement of water quality, compilation of environmental geologic maps of the Wilcox-Carrizo belt between the line separating Franklin and Titus Counties and the Texas-Arkansas border, and writing the summary report for the project.

Grant Number/Name: 14-08-0001-G-163

The Powder River Basin Mapping Program

Grantee: University of Wyoming Remote Sensing Laboratory, Laramie, WY 82070. Principal Investigator: R. W. Marrs.

Total Project Area: Johnson, Sheridan, and Natrona Counties, Wyoming (fig. 2 region 12).

Objectives:

The objectives of the study are to map existing land use, native vegetation, and undisturbed landforms in the north-central portion of the Wyoming part of the Powder River Basin. This is to be accomplished through use and interpretation of remote sensing data including satellite imagery and aerial photography. These efforts are designed to provide natural land-resource information in advance of widespread development of thick stripping-coal resources of the basin, in order to contribute to orderly and sound resource development and rehabilitation of mined lands. A secondary objective is to provide comparison of map results with USGS projects in the Montana portion of the Powder River Basin and in the eastern and western parts of the basin.

Progress in FY 76:

Scientists compiled land use, natural vegetation, and landform maps of Johnson County and most of Sheridan County, Wyo., and began work on similar maps for Natrona County.

Reports in FY 76:

Johnson County maps are in proof stage.

Work in progress in FY 77:

Compilation and evaluation of the Johnson County and Sheridan County maps continues; Natrona County maps are begun and compilation is in the early stages.

Planned changes in FY 77:

A shift of the study area into Natrona County is planned as soon as Johnson County maps are completed. These maps will contribute to folios of the Powder River Basin.

Grant Number/Name: $14-08-0001-G-187$

A Climatic Appraisal of the Rehabilitation Potential of Strippable Coal Lands in the Powder River Basin, Wyoming and Montana

Grantee: University of Denver (Colorado) Geography Department, University Park, Denver, Co 80210. Principal Investigator: T. J. Toy .

Total Project Area: Powder River Basin; 8,000 $\mathrm{km}^{2}$ (Wyoming, Montana) (fig. 2, region 12 ).

Objectives:

This project was designed to study the annual precipitation and evapotranspiration rates in the Powder River Basin and to develop a comprehensive and reliable basis for measuring the availability of water and the need for irrigation for revegetation of spoils from coal mining. A further objective was to adapt existing computer procedures in order to produce valid results for Environmental Impact Statements and other evaluations of impacts of mining on the environment.

Progress in FY 76:

The project was completed and eight climate- 
factor maps were submitted for publication. The report and maps are titled:

Maps of the Powder River Basin, Wyoming and Montana, showing:

A) Average annual precipitation

B) Average monthly precipitation

C) Length of growing season

D) Growing-season precipitation

E) Average monthly growing-season precipitation

F) Growing-season consumptive-water-use factor

G) Consumptive water use by natural irrigation

H) Irrigation water requirement; scale 1:500,000 with explanatory text, U.S. Geol. Survey Misc. Investigations Map __, in preparation. Submitted to USGS January, 1977.

Work in progress in FY 77: None; grant completed

Planned changes in FY 77: None

Grant Number/Name: $\quad 14-08-0001-G-415$

A Climatic Appraisal of the Rehabilitation Potential of Strippable Coal Lands in the Four Corners Area, Colorado-New MexicoArizona-Utah

Grantee: University of Denver (Colorado) Geography Department. Principal Investigator: T. J. Toy.

Total Project Area: San Juan Basin, Colorado and New Mexico and Black Mesa Basin, Arizona; about 100,000 $\mathrm{km}^{2}$ and 4,600 $\mathrm{km}^{2}$ (fig. 2, region 21).

Objectives: The study is designed to determine climatic factors that will influence rehabilitation of mined lands in the arid southwest and to develop a reliable and comprehensive basis for estimating water availability and need for irrigation in reclamation efforts. Secondary objectives are to adapt existing computer models to suit these particular circumstances, arrive at a valid estimate of irrigation water necessary for revegetation of coal mine spoil, and provide a comparison to a similar study carried out in the Powder River Basin.

Progress in FY 76: New grant FY 77

Reports in FY 76: None

Work in progress in FY 77:

An interim report is being compiled; single climate-factor maps of the San Juan Basin, with explanatory text, are being prepared; papers, some dealing with the grant, probably will be given at national meetings of scientific societies.

Planned changes in FY 77: None

Grant Number/Name: 14-08-0001-G-211

Inventory of Surface-Mined Lands and

Assessment of Reclamation Practices in Oklahoma

Grantee: Oklahoma Geological Survey, 830 Van Vleet Oval, Norman, OK 73069. Principal Investigator: K. S. Johnson.

Total Project Area: Statewide (Oklahoma) (fig. 2, region 7 ).

objectives:

Principal objectives of this grant are to make an inventory of past and present surface-mining activity of all kinds throughout the state in order to determine the extent of mining, types and quantities of material removed, conditions resulting from this activity, and the type and success of reclamation efforts at each site. Surfacemined materials include zinc, lead, copper, coal, asphalt, limestone, dolomite, clay, gypsum, granite, silica sand, and sand and grave1. Maps, diagrams, and reports will be compiled.

Progress in FY 76:

Amounts and locations of disturbed lands were compiled for about two thirds of Oklahoma's 77 counties. Field investigations were conducted into details of mining operations, amounts of disturbance, and environmental effects. Structuring of a computer file for storage and retrieval of data was completed and filing was begun.

Reports in FY 76:

Friedman, S, A., 1976, Map of eastern Oklahoma showing active coal mines: Oklahoma Geol. Survey Map.

Work in progress in FY 77:

Investigations will lead to the production of maps showing the location and extent of surface-mined lands since statehood, the type and amount of material removed, and the reclamation procedures followed.

Planned changes in FY 77: None

Grant Number/Name: 14-08-0001-G-241

Assessment of Environmental Effects of Strip Mining and Reclamation in Southeastern Kansas 
Grantee: Kansas Geological Survey, 1930 Avenue A, Campus West, Lawrence, KS 66044. Principal Investigator: R. G, Hardy •

Total Project Area: Southeast Kansas, approximately $10,000 \mathrm{~km}^{2}$ (fig. 2, region 7 ).

Objectives:

Objectives are to acquire and compile extensive and detailed information on the geology, coal and other resources, groundand surface-water conditions, soil, climate, biology, and land use in the coal mining area of southeastern Kansas. This information is to be used as a baseline against which to predict environmental changes as mining and restoration take place. The study includes a detailed study of overburden for reclamation purposes.

Progress in FY 76:

Progress toward project goals, compiled maps, and computer program.

Reports in FY 76: None

Work in progress in FY 77:

Progress continues toward successful fulfillment of the project objectives. Maps are being prepared, reports are being written, and computer programs are being developed.

Planned changes in FY 77: None

Major Accomplishments of Program in FY 76

The major accomplishments of the Energy Lands Program in Fiscal Year 1976 include the following:

--Completion of a contract with Mr, Horst Ueblacker, Consulting Mining Engineer, Lakewood, Colo., upon the submittal of his report, Surface Mining of Coal: A Discussion of Mining Methods, Reclamation Practices, and Environmenta1 Regulations of Foreign Countries.

--Publication or completion to branch submittal of several maps and reports, including surficial, interpretive, water, engineering geologic, and statewide energyresources maps.

--Response to congressional requests for information on alluvial valley floors as they might be affected by coal mining through a project of very rapid field reconnaissance mapping of alluvial valley floors in forty-eight 7-1/2-minute quadrangles in the Montana portion of the Powder River Basin.
--Contribution to Regional Environmental Impact Statements through compilation of state-of-geologic-knowledge reports on the southern Utah and western North Dakota coal regions and contribution of expertise to the eight other regional reports.

--Geologists now working in the Landslide Hazards Reduction Program mapped slope stability in a significant portion of the central and western Appalachian coal basin in Ohio, Pennsylvania, and West Virginia.

--Underwriting of the cost of and encouragement of investigations in baseline geochemistry of the Powder River Basin and other, smaller coal basins in the Western Interior.

--Monitoring and administering grants to State Surveys or universities in Oklahoma, Texas, Colorado, Kansas, Wyoming, West Virginia, and Ohio.

--First identification of large active and incipient landslides in urban and suburban areas of the Appalachian bituminous coal region, and open-filing of detailed maps of especially hazardous areas.

--Definition of regional climate and climatic needs of natural vegetation in the Powder River Basin, including amounts of water needed to augment natural precipitation.

--Preparation of a folio of detailed maps of the Gillette area, Wyoming, and of the entire Powder River Basin to show geologic, hydrologic, and other earth science influence on coal recovery and to show the energy facilities of the basin for planning purposes.

--Production of a series of maps of Johnson County, Wyo,, to illustrate the value of remote sensing methods in regional environmental assessment.

--Publication of a report on stability of highwalls in the strip mines in the western Powder River Basin that delineates factors of safety in designing highwall steepness.

--Publication of the Energy Resources Map of Colorado, which shows energy mineral deposits; handling, conversion, and transportation facilities; and power plants and major transmission lines; with similar maps of Wyoming and Utah, it contributes to regional planning.

\section{Program Goals for FY 77}

The emphasis of the Energy Lands Program will be shifted somewhat in its geographic scope 
in FY 77. A major goal is to respond to the Coal Exploratory Program of USGS and to the needs for geologic information pertinent to national and local legislation. Other principal goals include the following:

--Work closely with local, State, and Federal groups concerned with development of natural energy resources and national energy policy, and tailor the program even more closely to the national need.

--Coordinate investigations in western energy lands with those of Water Resources and Conservation Divisions to avoid duplication of effort, contribute to the national scientific effort to aid in responsible development of energy resources, and contribute to folio maps of coal regions currently being prepared by USGS.

--Begin new projects in coal-bearing areas of the San Juan Basin, Alaska, Montana-North Dakota, and east-central Utah; a nationwide project of carbonates for $\mathrm{SO}_{2}$ scrubbing; a climatic study of the Four Corners coalbearing region; and a study of effects of off-road vehicles on soil breakdown.

--Develop new grants to appropriate State Geological Surveys and universities to help states in appraisal of the environmentalgeologic problems of their energy lands.

--Complete surficial geologic mapping in the eastern Powder River Basin and begin preparation of derivative and interpretive reports based on that basic information.

--Complete compilation by remote sensing techniques of land-use, landform, and vegetation maps of Johnson and Natrona Counties, Wyoming,

--Continue engineering-geologic studies in the western Powder River Basin, completing reports in specialized parts of the studies.

--Continue research into rates of erosion and surficial and bedrock geologic mapping in northwest Colorado energy lands.

--Complete some basic mapping in the Kaiparowits Plateau and begin interpretive phases; continue research in rates of erosion on Black Mesa.

--Complete environmental-geologic studies of the Texas Lignite Belt, and continue them in Oklahoma and Kansas.

--Begin age-dating studies in energy lands, based on radioactive decay of natural isotopes.

--Continue baseline geochemistry studies in western energy lands.
SUMMARY OF RESULTS OF RESEARCH, FY 76

Scientists working in the Energy Lands Program investigated several diverse subjects as part of the research aspect of the missionoriented program. Paleoclimatic conditions in the arid southwest, having long-range bearing on potential for reclamation of mined lands, were deduced from tree-ring analysis, fission-track and ${ }^{14} \mathrm{C}$ dating, comparative alluviation, and archaeological remains. Quantification of abstract aesthetics was applied to computercomposite mapping of the potential for minedland reclamation in a portion of the Northern Great Plains. Surficial and engineering geologic maps of parts of the Powder River Basin were constructed as bases for interpretive and derivative maps that will help in regional planning. Topical studies in landslide hazards, coal-mine deformation, and the stability of strip-mine highwalls and of surfaces over underground mines were completed and their transfer value was assessed. A new Quaternary stratigraphy in northwestern Colorado was compiled, based in part on age dating of volcanic ash contained in sediments and sedimentary rocks. The State geological agencies in Texas, Oklahoma, and Kansas carried out research in environmental geology of coal lands in those states.

\section{STRATIGRAPHY AND PALEOCLIMATE OF THE BLACK MESA BASIN}

By

Thor N. V. Karlstrom

Paleoclimatic studies in the Black Mesa region suggest that a substantial change toward cooler, wetter climate should occur within the next few decades. Converging lines of scientific evidence provide a basis for the use of past climatic changes to project future climatic trends. Understanding these trends is essential to meaningful long-range environmental evaluation and planning.

A major objective of the Black Mesa project is to provide a geologic basis for evaluation of the effect of surface mining on a fragile southwest desert environment. Geologic, biologic, and archeologic indices allow objective assessment of the magnitude and frequency of past natural environmental changes and open the way to prediction of natural change in the future.

A major breakthrough in microstratigraphic analysis resulted from work done jointly with Dr. Jeffrey Dean, Tree-ring Laboratory, University of Arizona. Dean discovered that tree sections collected from numerous buried juniper forests in the region ( $f i g, 3$ ), and from buried detrital wood, have ring patterns that commonly are cross-datable with southwest 


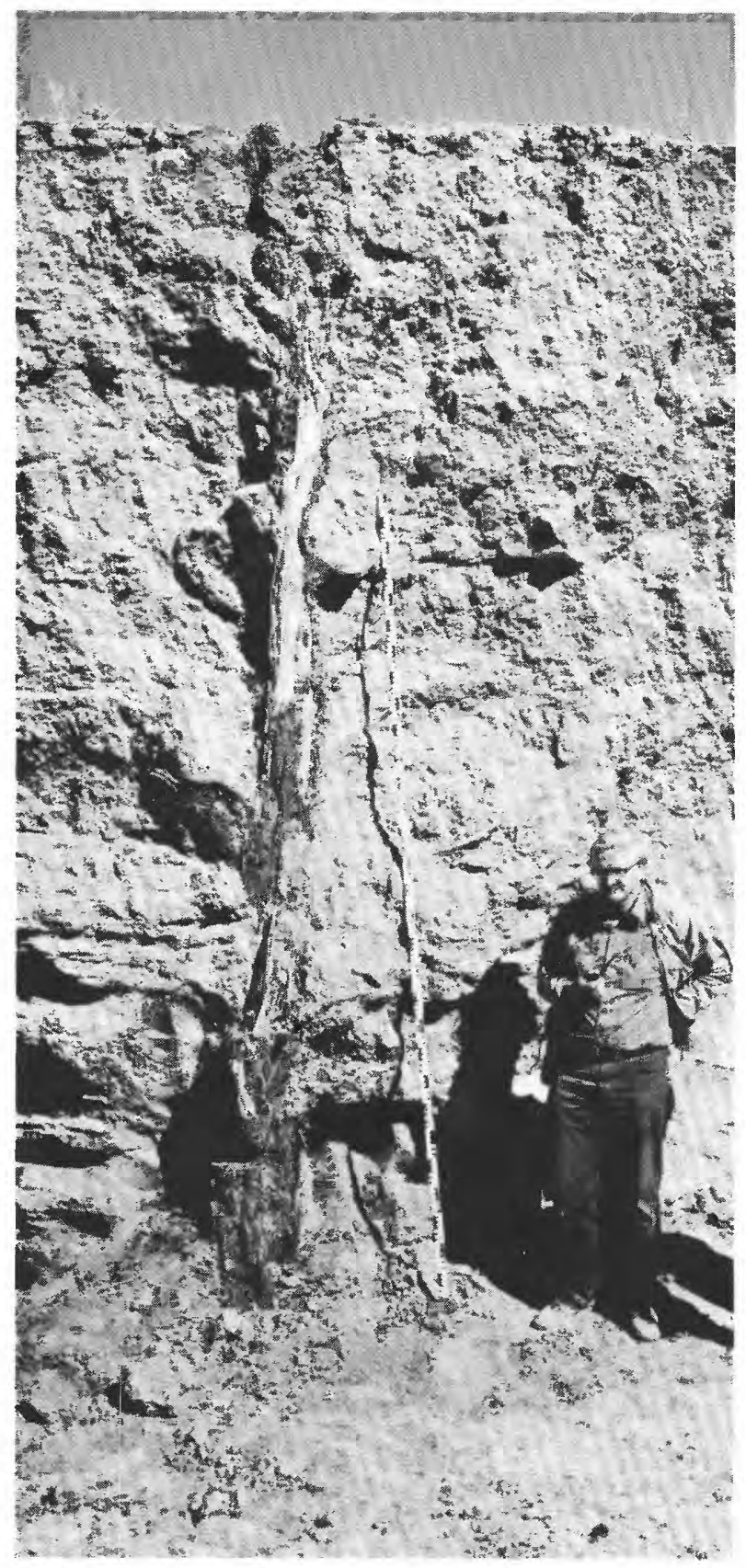

Figure 3.--Discovery tree of buried juniper forest in Dead Jumiper Wash, Black Mesa, Ariz. Tree-ring cross dating of sections cut from this and numerous other buried and living trees in the area indicates that the buried forest germinated on an ancient arroyo floor between A.D. 1350 and A.D. 1450, and was buried by the $\mathrm{Z}$ sediments exposed in the arroyo wall. dendrochronologic records. This cross-dating technique permits precise geologic dating (within 1-25 years) of enclosing sediments. Tree-ring germination and death dates have been obtained from more than 100 tree sections. The results confirm the validity of dates obtained archeologically and the general validity of most ${ }^{14} \mathrm{C}$ results obtained from charcoal and other buried organic material.

Project scientists recognize a systematic pattern of past hydrologic changes that were essentially contemporaneous within the drainage basins of the Black Mesa region. Dating of stratigraphic sections reveals a series of thick primary depositional units with intervening thinner erosional units and developed soils. The main component of the emerging hydrologic pattern is a cycle with primary soil-forming or drought intervals recurring every 500-600 years. Each primary depositional unit, informally designated $\mathrm{T}$ (oldest) through $\mathrm{Z}$ (youngest), is made up of a series of subordinate units whose grain size becomes finer toward the top of the unit. Subunits directly dated by tree-rings, archeology, and ${ }^{14} \mathrm{C}$ define a pattern of secondary depositional impulses (about 100 years or less in duration) centered on the peaks of the broader (about 550-year) alluvial epicycles.

On the basis of these discoveries, scientists have defined three principal types of alluvial stratigraphy: superposed stratigraphy, inset-terrace stratigraphy, and mixed stratigraphy (fig. 4). The data demonstrate similar depositional histories of drainage basins throughout the region, although the dated local sections are associated with differing numbers and heights of terraces. Numerous dated sections in the region show superposed stratigraphy ( $\mathrm{fig}, 4 \mathrm{~A}$ ) and various combinations of mixed stratigraphy (fig, $4 \underline{C}$ ). As yet no sections have been dated that comprise only inset-stratigraphy having only one depositional unit beneath each terrace level (fig. 4B).

The correspondence of alternating depositional and nondepositional epicycles at widely separated localities indicates that essentially synchronous, climatically induced hydrologic changes have been the main factor controlling alluvial processes throughout the region since Pleistocene time. The same conclusion was reached by Haynes (1968) from his pioneer analysis of ${ }^{14} \mathrm{C}$-dated alluvial sections throughout the southwest; and by Hevly and Karlstrom (1974), who based their evaluation on numerous ${ }^{14} \mathrm{C}$-dated pollen and depositional records available from the southwest, Alaska, and the midcontinent. 


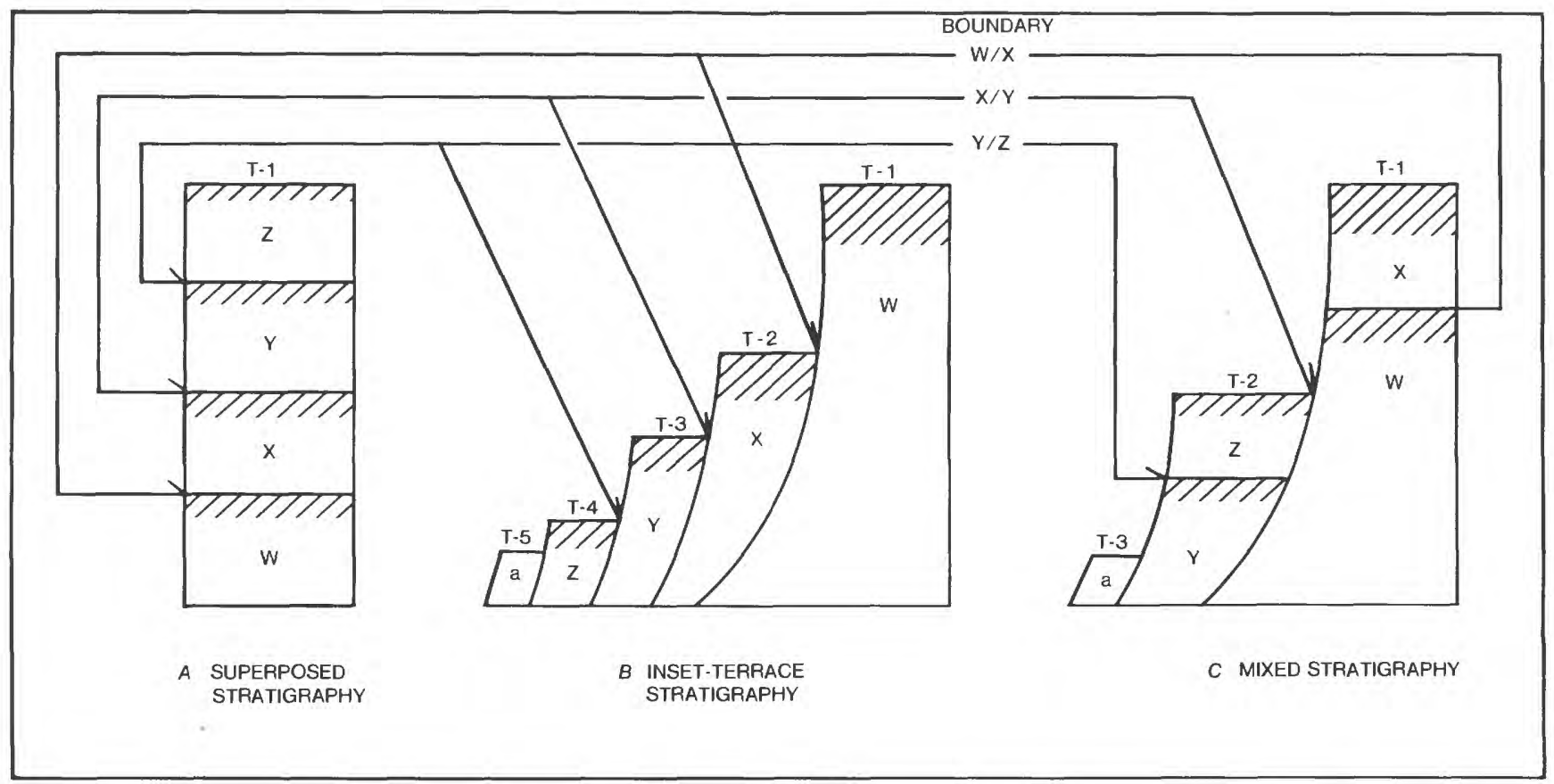

Figure 4.--Different types of terraced stratigraphy on Black Mesa. Depositional units W to $\mathrm{Z}$ are defined by dated reference boundaries representing estimated midpoints of intervening nondepositional intervals marked by soils and unconformites. The $\mathrm{Y}-\mathrm{Z}$ boundary is about $\mathrm{A} \cdot \mathrm{D}$. 1450; the X-Y boundary about A.D. 875; and the W-X boundary about A.D. 350. Deposition of units is associated with young arroyo-floor terraces dated between about A.D. 1900 and 1973. Variable soil ( $\mathrm{T}-1$ to $\mathrm{T}-5$ ) thickness (hachures) is a function of relative duration of subaerial exposure and weathering before burial beneath younger terraces.

Dated depositional breaks in the alluvial record coincide closely with ceramic dated phase-breaks in the Black Mesa archeological record and with drought intervals recorded in the regional dendroclimatic record (combined normalized tree-ring indices of Rio Grande, Mesa Verde, Navajo Monument, and Flagstaff, Ariz; Fritts, 1965). These temporal coincidences strongly suggest that prehistoric cultural adaptations occurred on Black Mesa largely in response to repeated intervals of environmental stress (Karlstrom and others, 1974; fig. 3). As noted by Gumerman and Euler (1976, p. 170), this conclusion does not preclude the important effect of population pressures and other social factors, but emphasizes that episodic changes in past physical environments played a significant role in the general timing and direction of rapid human adaptive change, migration, and site abandonment. The fact that secondary drought intervals evidently were of sufficient magnitude to influence the cultural development of prehistoric man favors the conclusion that future comparable high-frequency events on Black Mesa will affect modern man's activities and environmental planning as well.

The apparent systematic pattern of the emerging geologic record and its consistency with archeological and biological indices suggest a sound basis for estimating the magnitude and frequency of future environmental changes on Black Mesa. Figure 5 summarizes the critical geologic, archeologic, and biologic data from Black Mesa for the past 1,300 years and schematically provides a first approximation for predicting future trends. The apices of the reconstructed low-frequency hydrologic curve are approximately centered in the primary depositional units and coincide with minor unconformities and weak soils dated at about A.D. 600, A.D. 1150, and A.D. 1700. The troughs of the curve are placed at the estimated midpoints of the intervening major nondepositional intervals, as these are closely bracketed by dated stratigraphic horizons.

Extrapolation of the geologically derived low-frequency trends suggests that the modern arroyo-cutting episode, which began after the $1850^{\circ} \mathrm{s}$ in the southwest, may represent a drought interval of a magnitude corresponding to the about 550-year cycle that should terminate (and reverse itself) around the beginning of the 2lst century (or within 25 years). One likely extrapolation of the superposed higher frequency and more sensitive tree-ring record of change suggests a turning point in the major drought 

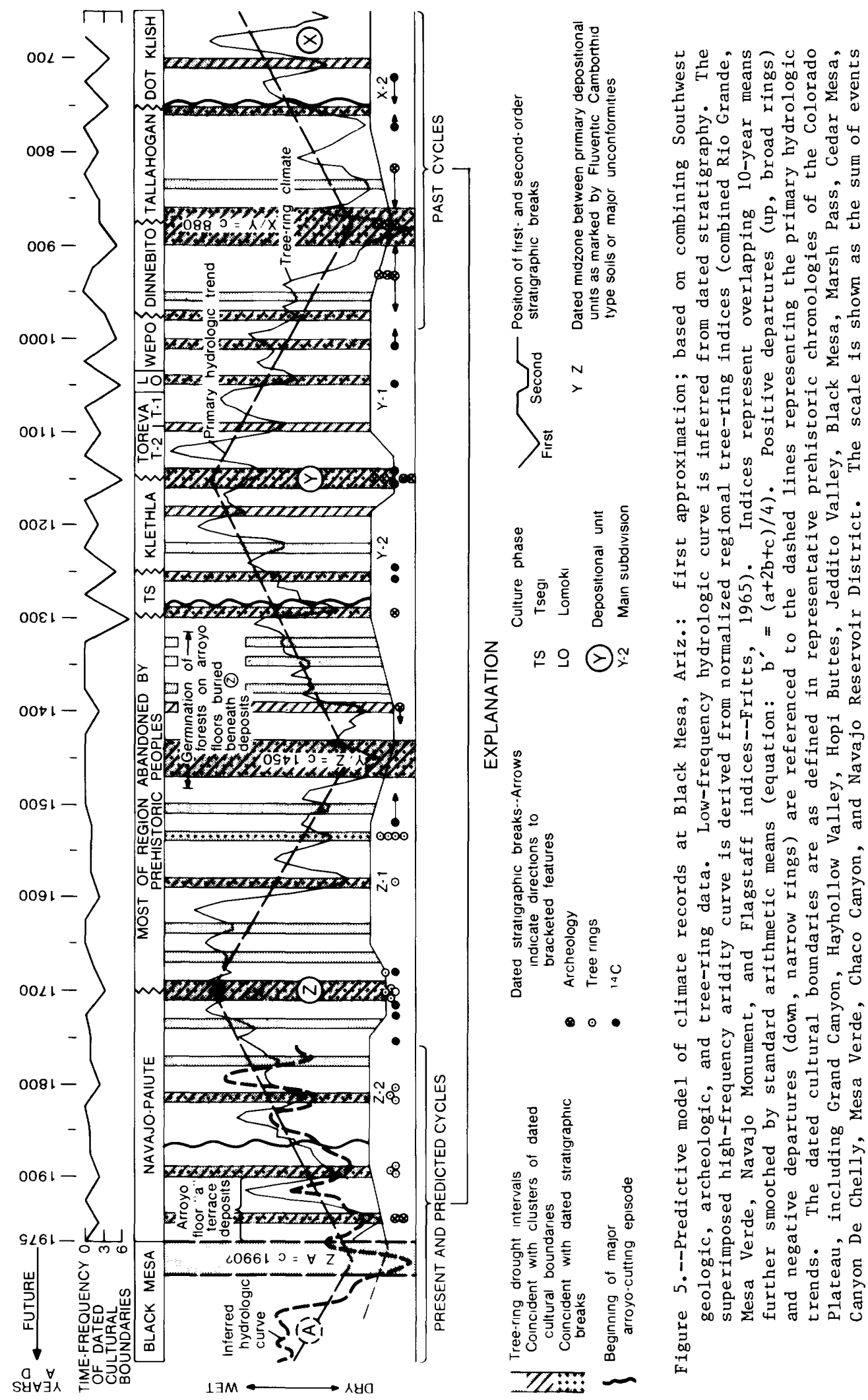

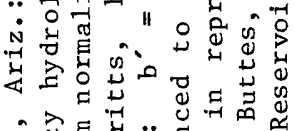

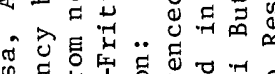

ô

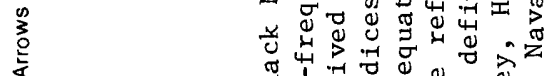

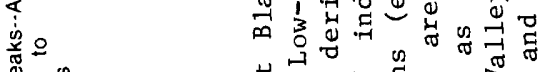

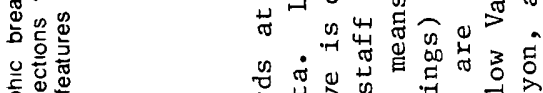

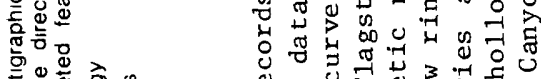

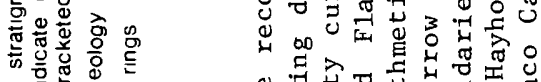

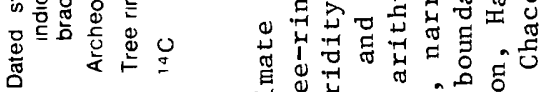

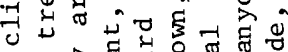

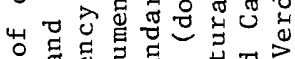

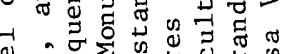

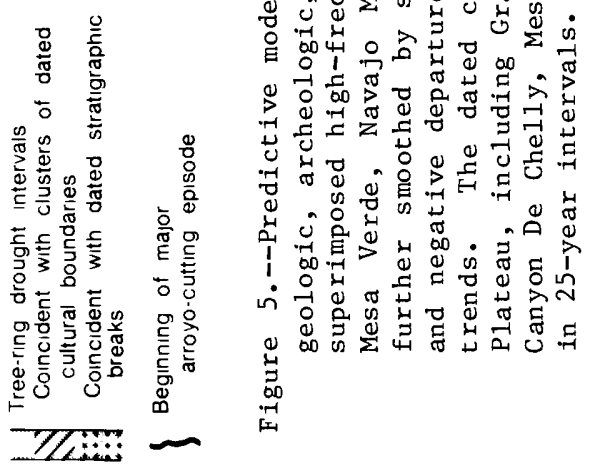


trend at about A.D. 1990 years, with an abrupt recovery to wetter conditions within 50 years. If so, drying conditions that resulted in arroyo cutting and progressive deterioration of agricultural potential in the region during the past 100 years may shift toward wetter climate, general aggradation of arroyo floors, rising water tables, and increasingly favorable grazing and farming conditions in the near future. It is clear from the record that static persistence of the present range of hydrologic and climatic fluctuations is extremely unlikely, and that comparable ranges of environmental change as geologically recorded for the past should be considered in environmental planning for the future.

\section{RECLAMATION-POTENT IAL MAPPING OF STRIPPABLE} COAL LANDS IN SEMIARID REGIONS

\section{By}

David W. Moore

Reclamation potential, as used in this study, is the likelihood of returning the environment to a desirable physical condition following surface mining. A procedure for mapping this abstract concept has been developed by the U.S. Geological Survey. In this procedure, the overall reclamation potential of land parcels is obtained by adding the reclamation potentials of several component environmental factors which have been estimated from available results of reclamation research. The factors include water, wildlife, and scenic resources, as well as land use by man.

The need to show the potential for reclaiming the environment in regions of strippable coal was a major conclusion of the 1974 report of the National Academy of Sciences (1974, p. 10). More recently, this need was noted throughout the 1976 congressional hearings on the new Federal Coal Policy (U.S. Congress, 1976, p. 97, 144, 166, 172). Retention of environmental quality in coal lands requires knowledge of the reclamation potential of land parcels, so that unusually vulnerable and valuable environments may be considered for exclusion from mining or for special reclamation practices.

Relative reclamation potential, expressed as high, intermediate, or low, has been mapped at 1:100,000 scale in about $500 \mathrm{~km}^{2}$ of land underlain by strippable coal near Gillette in northeastern Wyoming. The maximum resolution of mapping is a rectangular cell the size of an upper case typewriter character $(3.2 \times 2.5 \mathrm{~mm})$ which represents 8 hectares on the ground. The mapped area lies within a larger region trending

1 The 8-hectare parcel of land has sides $320 \times 250 \mathrm{~m}$. northward along the eastern margin of the Powder River Basin, which is underlain by about 18 billion metric ton of strippable coal (fig, 6).

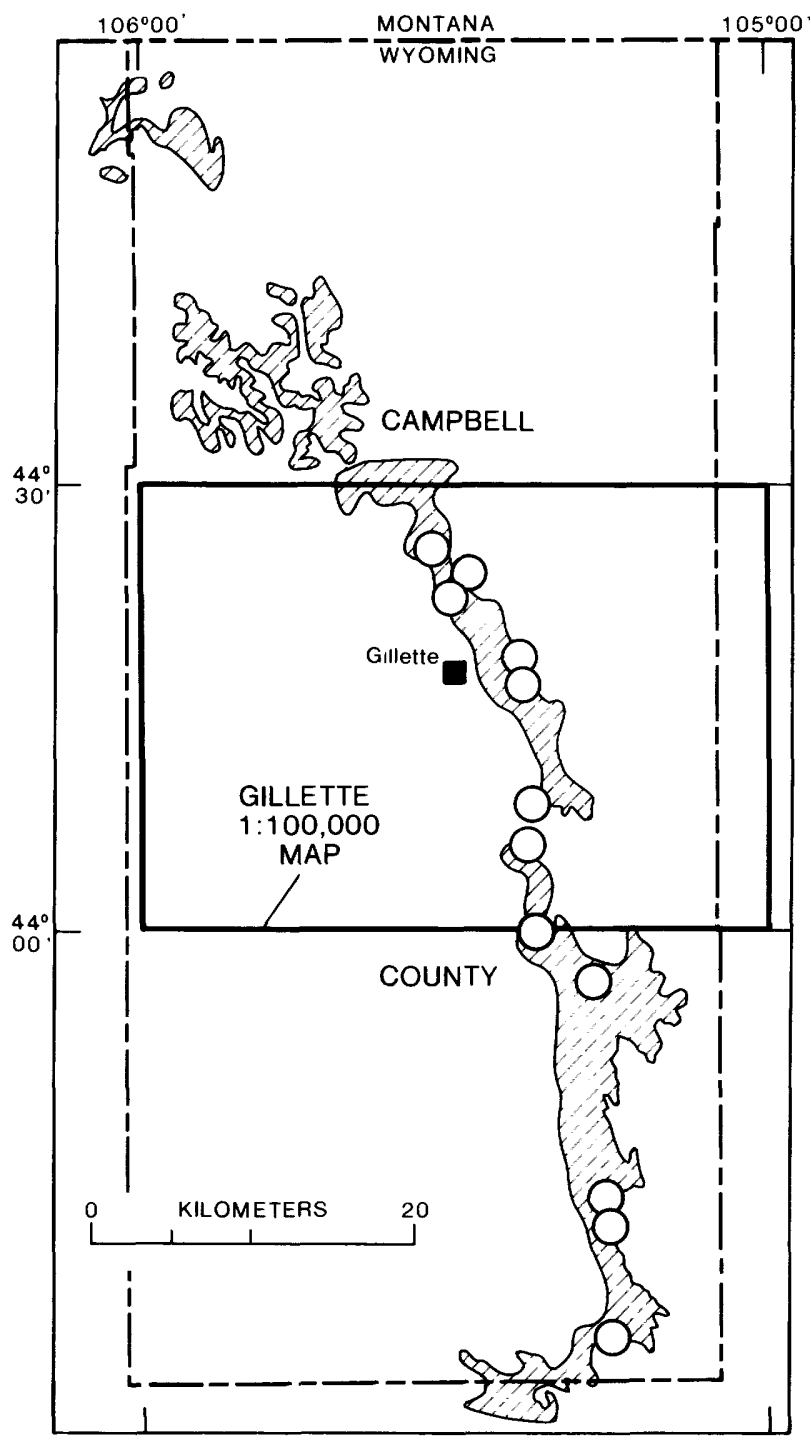

Figure 6.--Strippable coal (patterned) in the Powder River Basin, existing or proposed surface mines (circles), and study area within the Gillette 1:100,000 quadrangle map.

\section{Evaluation of Reclamation Potential}

Reclamation standards and predictions about the chances of actually fulfilling these standards are needed to evaluate reclamation potential. Reclamation standards define the minimal physical conditions to which disturbed land must be returned after cessation of mining; they were defined following federal reclamation 
guidelines for coal lands (U.S. Department of the Interior, 1976). Reclamation potentials of individual environmental factors were estimated from the available results of reclamation research (for example, Van Voast and others, 1975) and were ranked on a likelihood scale ranging from 0 to 9 . Zero is the lowest (essentially impossible) and 9 is the highest estimated likelihood of successfully reclaiming the factor to its standard. The sum of likelihood scores for six environmental factors is used as an indicator of the overall reclamation potential of the environment. Predictions of reclamation potential in 1977 are, of necessity, estimates, because data are too few to permit formal probability analysis. Probability analysis, as a basis for predicting reclamation potential, would require much data resulting from the ideal situation of 5-10 years of instrumented measurements of physical, chemical, and biological systems on mine spoil in semiarid regions.

The past several years of research are beginning to yield data for a few factors, notably revegetation of spoil in semiarid regions. Revegetation research has been underway at Colstrip, Mont., since 1971, for instance (Hodder and others, 1971). However, few measurements exist for other factors such as ground-water quality, livestock grazing, and surface-water quantity in mine spoil environments.

\section{Procedures of Composite Mapping}

The main steps of composite mapping of reclamation potential are preparing maps of environmental factors at a common scale, recording the likelihood ranking scores for individual factors on grids, converting gridded information to matrices (creating computer files), and overlaying matrices by computer to produce the reclamation potential map (composite map).

Six environmental factors were mapped and evaluated in the pre-mining environment of the strippable zone of the Wyodak-Anderson coal

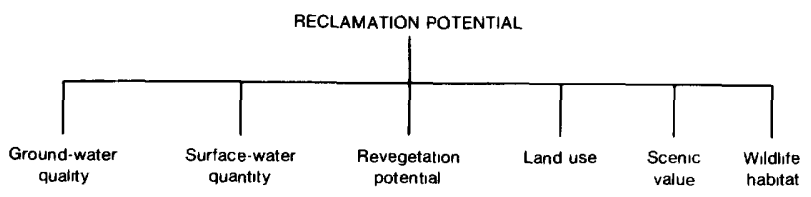

Figure 7.--The six major environmental factors which were evaluated for their reclamation potential. High values of revegetation potential contribute to high reclamation potential. Revegetation potential is a composite of evaluations of moisture requirements, slope, topographic aspect and closed depressions, soil quality, and sediment yield. Wildlife habitat is a composite of large- and small-game habitats. deposit in the Gillette quadrangle: groundwater quality, surface-water quantity, revegetation potential, land use, scenic value, and wildlife habitat. Factor subtypes (for example, big-game and small-game habitat subtypes make up the wildlife habitat factor) were mapped for each factor from field observations, aerial photographs, or data and maps of previous workers (for example, Maiss, 1976). These factors and factor subtypes were determined to be of greatest use for experimental map purposes through the writer's personal knowledge and discussions with colleagues in USGS, U.S. Forest Service, U.S. Soil Conservation Service, and State agencies.

Reclamation-potential scores for all subtypes of each environmental factor were determined, using the likelihood scale for each. These scores were recorded as single digits from 0-9 inclusive, on an 8-hectare cell grid laid over the factor map. In this digitized format, the information is uniquely locatable on the base map and is easily processed by the computer. The computer created a matrix of reclamation-potential scores from the digitized data using a set of programs called GMAPS $^{2}$ (Turner, 1976). A composite map was made by adding the matrices of all factors using the computer (fig, 8). Matrices may be weighted so that changes on the composite map caused by emphasizing the importance of one or more factors over the others may be seen. For an assessment that emphasizes factors important to wildlife habitat and scenic resources, the following weighting was used:

$$
\mathrm{RP}=1 \mathrm{GW}+2 \mathrm{SW}+2 \mathrm{RVP}+1 \mathrm{LU}+4 \mathrm{SV}+3 \mathrm{WH},
$$

where RP is the matrix of sums of reclamationpotential scores and members on the right side of the equation are matrices for environmental factors: GW, ground-water quality; SW, surfacewater quantity; RVP, revegetation potential; LU, land use; SV, scenic value; and WH, wildlife habitat. Elements of the resultant matrix of sums indicate numerically the relative reclamation potential of small individual parcels of the strippable coal region. Three classes, high, intermediate, and low, were determined by dividing the frequency distribution of sums into thirds. A composite map then was printed by the computer line printer with different symbols creating contrasting gray tones representing the three classes of reclamation potential (fig. 9).

\section{Applications}

The following example is pertinent to illustrate the need for reclamation-potential

General Map Analysis and Planning System (GMAPS), developed by A. K. Turner, Colorado School of Mines, Golden, Colo. 


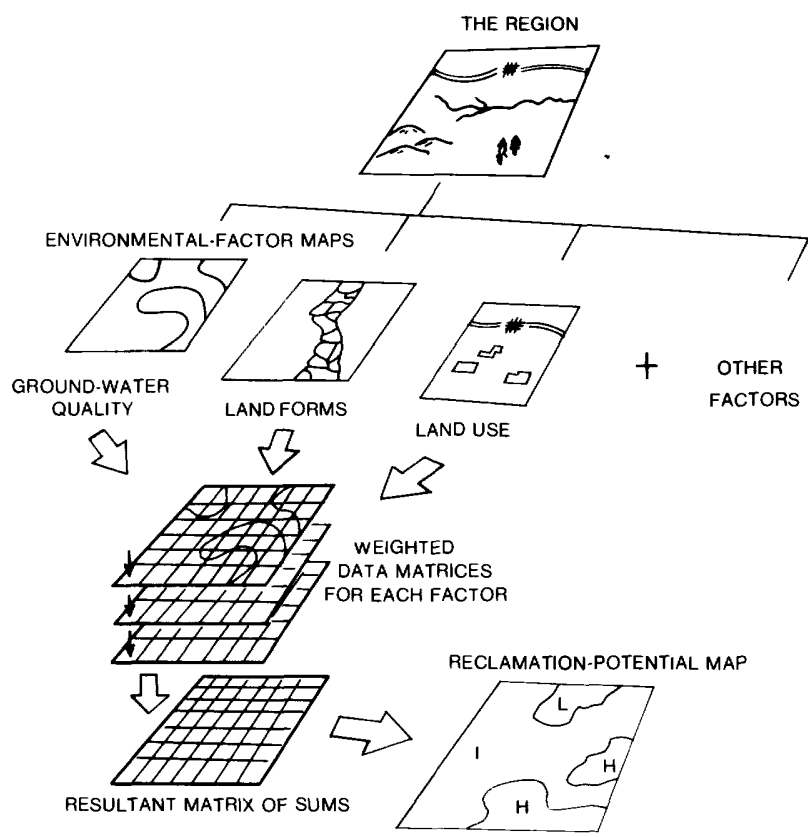

Figure 8.--Diagram showing main steps of composite mapping used to make the reclamation-potential map (modified from Turner, 1976), L, I, and $H$ on the map represent low, intermediate, and high potential for reclamation.

mapping. The total area that will be disturbed by the year 1990 in the strippable coal region shown in figure 6 (diagonal pattern is about 815 $\mathrm{km}^{2}$ ) is estimated at about $140+15 \mathrm{~km}^{2}$. After about 1980, the disturbed terrain that will be apparent during any given year may be about 25$40 \mathrm{~km}^{2}$. These figures assume 12 mines, each producing about 5-18 million metric tons per year, and they assume that reclamation will be contemporaneous with mining operations. Operations at these scales will cause great environmental disruption and ensuing reclamation efforts; potential maps illustrate the scope of these efforts.

Reclamation-potential maps can be used by resource managers in selecting areas suitable for leasing. The maps also can be used in areas already leased to locate environmentally sensitive sites which may require provisions in the mine plan to reduce environmental losses. This method of mapping reclamation potential can be used in other regions having considerable variety and density of environmental "baseline" data. The size of the land parcel represented by the map cell should be chosen before mapping of environmenta1 data begins, so that the implied areal reliability of the reclamationpotential map is representative of the environmental source data.

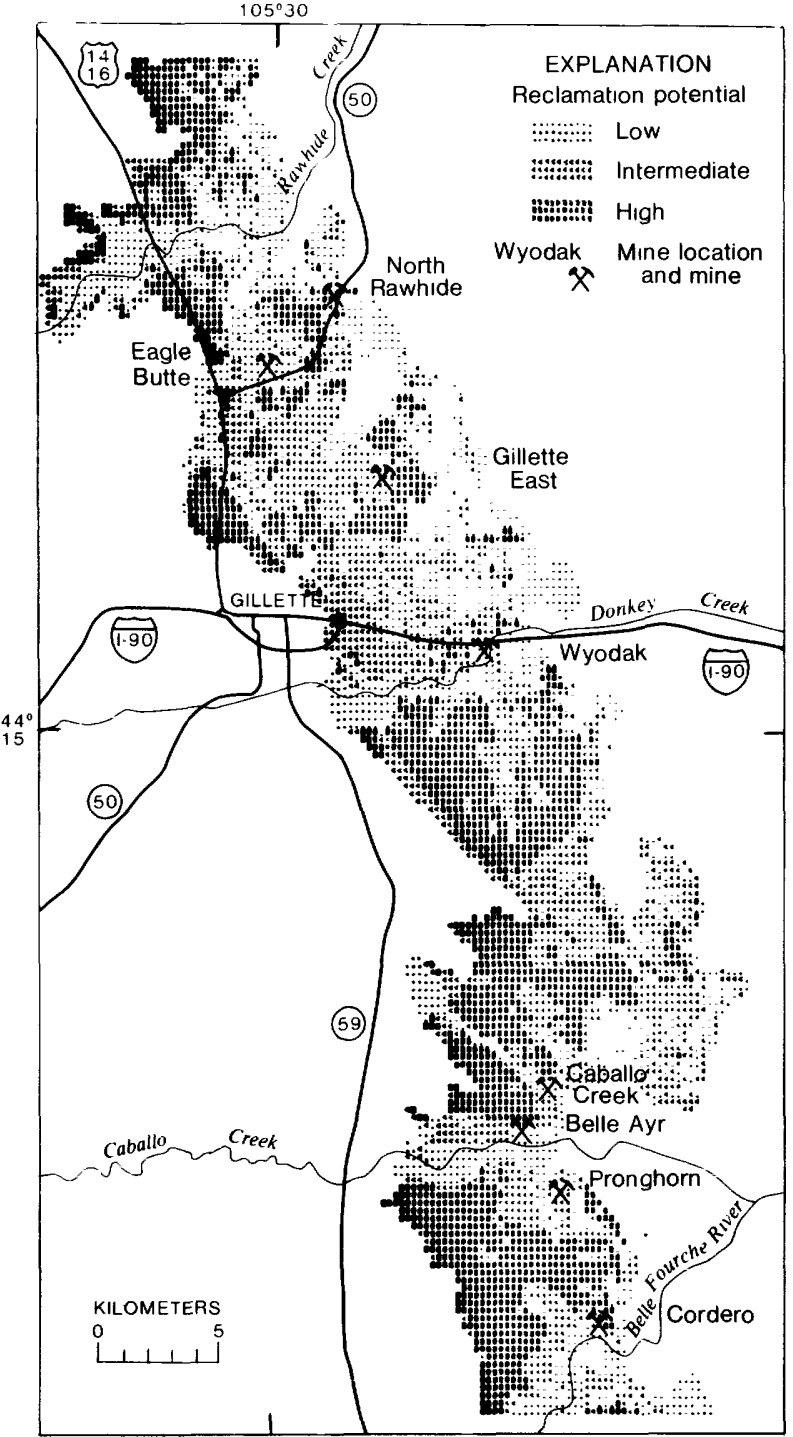

Figure 9.--Reduced map of reclamation potential for the strippable-coal region of the WyodakAnderson coal deposit in the Gillette 1:100,000 quadrangle. Individual cells represent 8 hectares. The right edge of the zone is about $0.5 \mathrm{~km}$ east of the coal outcrop; the left edge shows where depth to the top of the coal is about $90 \mathrm{~m}$.

\section{SURFICIAL GEOLOGIC MAPPING IN THE EASTERN POWDER RIVER BASIN}

By

Donald A. Coates

Surficial geologic maps are being made of forty-four 7-1/2-minute quadrangles and half of each of two 15-minute quadrangles along a corridor of strippable coal that runs the length 
of Campbell County in northeastern Wyoming ( $\mathrm{fig}$. 10). This area, underlain by gently westwarddipping rocks on the eastern flank of the Powder River Basin, contains some 14 billion metric tons of subbituminous coal in beds $15-30 \mathrm{~m}$ thick beneath less than $60 \mathrm{~m}$ of overburden (Keefer and Hadley, 1976). Several large strip mines currently are in operation, and by 1985 each of about a dozen such mines are projected to be producing on the order of 10 million metric tons of coal annually.

The bedrock exposed at the surface in the study area comprises the Fort Union Formation, deposited in Paleocene time (between 65 and 53 million years ago), and the Wasatch Formation,

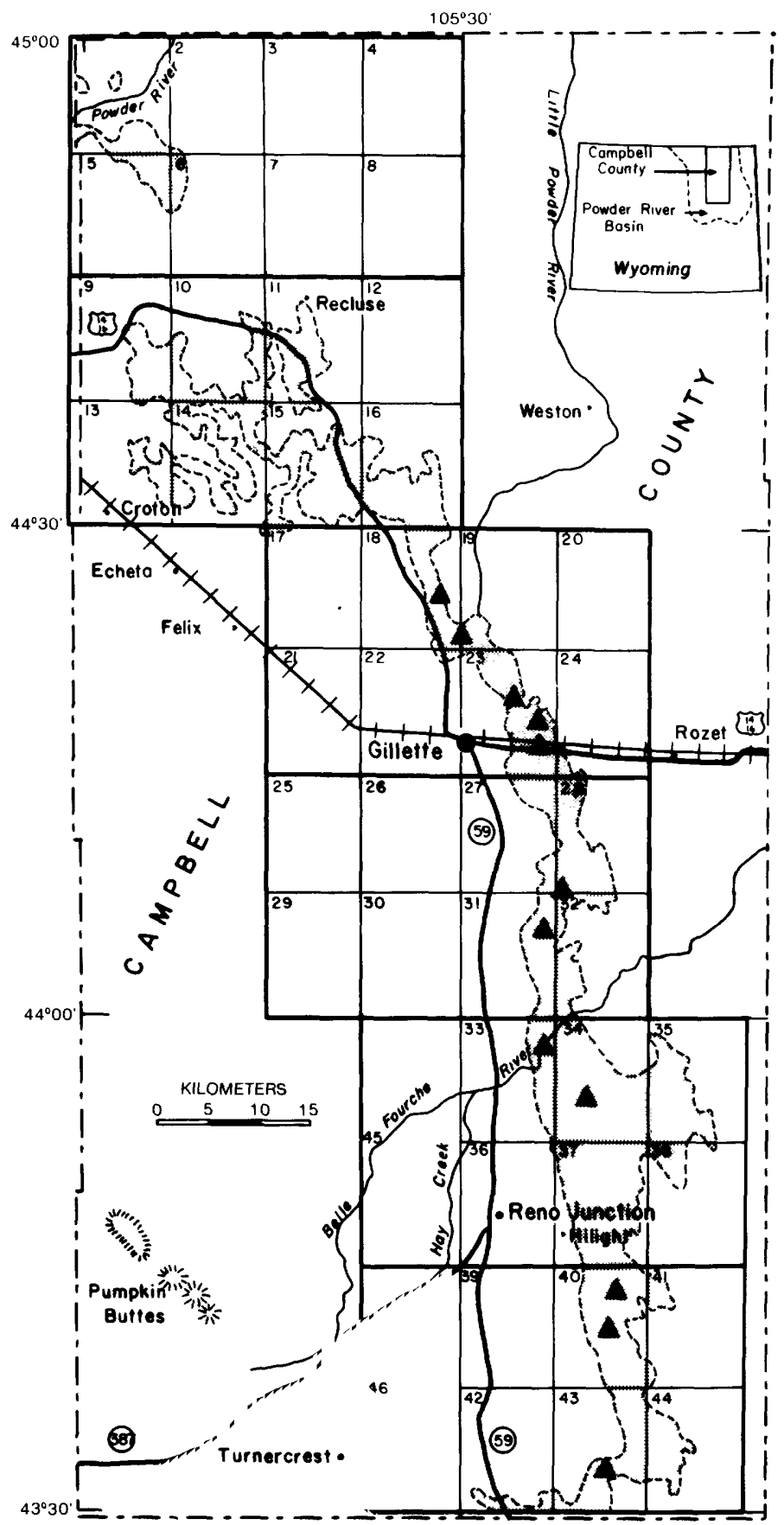

\section{EXPLANATION}

Outline of $71 / 2$ and 15-mınute quadrangles in which surficial geologic maps are being made

Outline of blocks of quadrangles that will be combined for publication at 1:50 000

\section{Approximate area of strippable coal deposits,} modified from Keefer and Schmidt (1973)

Location of active or proposed coal strip mine

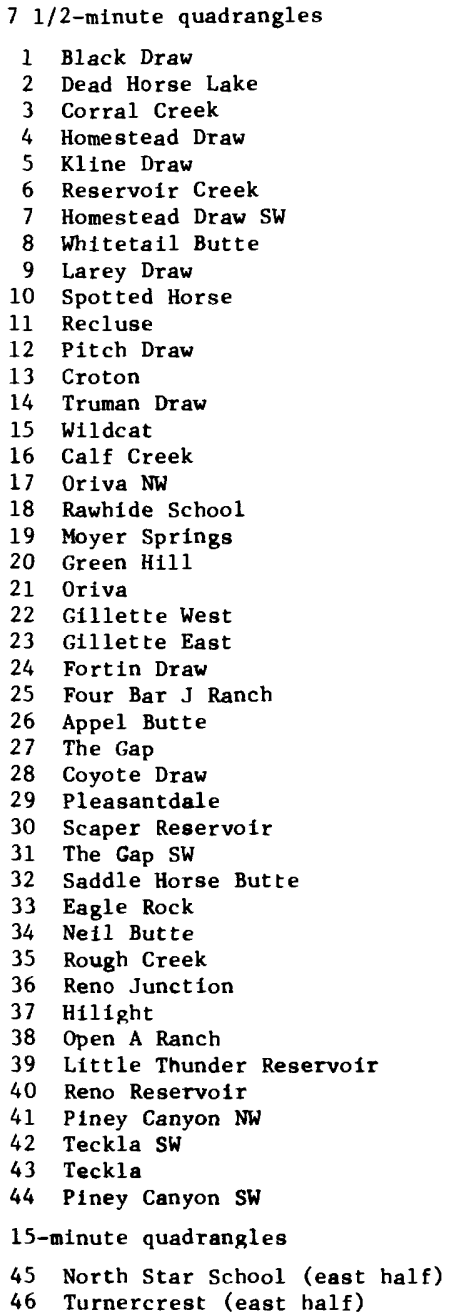

Figure 10.--Location of surficial geologic mapping in progress in FY 76 in the eastern Powder River Basin, Campbe11 County, Wyo. 
deposited in Eocene time (between 53 and $38 \mathrm{~m} \cdot \mathrm{y}$. ago). There are many coal seams in both formations, but the seam that is of greatest economic interest, the Wyodak-Anderson seam, lies in the upper part of the Fort Union Formation and extends westward downdip beneath the Wasatch Formation.

Although there are some differences between the rocks of the Wasatch and the Fort Union, both formations are mainly soft shale and sandstone that disintegrate upon weathering. As a result, the surface materials in the region, including the stream sediments, are mostly fine grained. Generally the significant distinctions among surface materials are related more to processes of weathering, erosion, and deposition than to grain size. Therefore, the surficial units mapped are defined in terms of the processes that formed them (table 1).

The landscape formed on Wasatch Formation south of Gillette is characterized by rolling terrain having a few tens of meters of gentle relief, punctuated by scattered groups of steep hills capped by "clinker" (bedrock that has been baked and fused by the burning of coal beds). Unbaked bedrock generally crops out only on the edges of hilltops and on the sides of steep valleys. Flat uplands in some places areancient erosion surfaces. Northwest of Gillette the landscape developed on the Wasatch is more

Table 1. Mapped surficial geologic units and underlying bedrock in the eastern Powder River Basin, Wyo.

\begin{tabular}{|c|c|}
\hline Type of unit & Map unit \\
\hline $\begin{array}{l}\text { Alluvial } \\
\text { sediments }\end{array}$ & $\begin{array}{l}\text { Flood-plain and channel alluvium } \\
\text { Tributary alluvium } \\
\text { Terrace alluvium } \\
\text { Fan and pediment alluvium, undifferentiated } \\
\text { High-level alluvium and residuum, undifferentiated } \\
\text { Slopewash and slack-water alluvium } \\
\text { Residuum and slopewash alluvium, undifferentiated }\end{array}$ \\
\hline \multirow[t]{2}{*}{ Lacustrine sediments } & Playa-lake sediments \\
\hline & $\begin{array}{l}\text { Dune sand } \\
\text { Eolian sand and silt, undifferentiated } \\
\text { Residuum and eolian sand and silt, undifferentiated }\end{array}$ \\
\hline $\begin{array}{r}\text { Mass-wasting sediments } \\
\text { Residual } \\
\text { deposits }\end{array}$ & $\begin{array}{l}\text { Colluvium and residuum, undifferentiated } \\
\text { Residuum on Wasatch Formation } \\
\text { Residuum on Fort Union Formation } \\
\text { Residuum and slopewash alluvium, undifferentiated } \\
\text { Residuum and eolian deposits, undifferentiated } \\
\text { Colluvium and residuum, undifferentiated }\end{array}$ \\
\hline Bedrock & $\begin{array}{l}\text { Baked and fused bedrock ("clinker") } \\
\text { Wasatch Formation (EOCENE) } \\
\text { Fort Union Formation (PALEOCENE) }\end{array}$ \\
\hline other & Disturbed terrain \\
\hline
\end{tabular}


rugged, having up to $150 \mathrm{~m}$ of local relief. "Clinker" outcrops here are more common on the slopes than on the hilltops.

The dominant surface material in the area underlain by the Wasatch Formation is residuum, weathered bedrock that has not been transported. Residuum is porous, permeable, moderately weathered, arkosic, sandy material, which forms land commonly used for grazing and, where water is adequate, for dry-land farming. Slopewash alluvium is abundant in this landscape and is thick enough to be mapped on many of the lower slopes. It is especially common bordering the many depressions that have been produced by wind erosion and now contain playa lake sediments. Stabilized sand dunes are present in some areas, and thin, discontinuous deposits of windblown sand and silt are widespread, especially on the flatter land south of Gillette.

The part of the study area underlain by the Fort Union Formation lies mostly in the steep, dissected region known as the Rochelle Hills. Where the thick coal bed in the upper part of the Fort Union Formation has burned, the overlying bedrock has been baked and fused through a thickness of commonly more than $30 \mathrm{~m}$. Because these baked rocks are substantially more resistant than are rocks above and below, erosion has produced a landscape in which the baked zone forms broad flat divides that are separated from the major valleys by steeply dissected areas having as much as $100 \mathrm{~m}$ of relief. Surface materials in these dissected breaks are chiefly residuum, bedrock outcrop, colluvium, and slopewash alluvium. Pediments, which are gentle bedrock slopes partly covered with alluvium, are common at the base of the breaks; and alluvial fans have formed where tributaries enter the main valleys.

Rocks of the upper Fort Union Formation generally are less permeable than rocks of the Wasatch Formation and form less fertile soil. Bedrock is more commonly exposed in the Fort Union terrane, and a finer textured, better developed drainage network typically has developed. Pasture is more sparse in this Fort Union terrane and dryland farming is uncommon.

Repeated downcutting, filling, and widening of the major stream valleys has produced a sequence of terraces and fill deposits, the history and timing of which is not yet wholly understood. The valley bottoms are important in this study because a significant amount of the bottom land is used for hay production, which supports the local cattle industry. The productivity of the valleys depends on subirrigation from the water table or flood irrigation during flow of these ephemeral streams. These alluvial valley floors, ${ }^{3}$ which

3 "Alluvial valley floors" are defined as the unconsolidated stream-laid deposits holding streams where water availability is sufficient for subirrigation or flood irrigation agricultural activities: . . (U.S. Senate, 1977, ms. p. 132). figure importantly in environmental constraints in recent proposed strip mine legislation (U.S. Senate, 1977), are estimated to cover about 3 percent of the surface-minable coal of the Powder River Basin (John Hardaway, Environmental Protection Agency, Denver, oral commun., 1976).

Interpretive maps at the scale 1:24,000 are being prepared for selected quadrangles in which rapid development is expected, in order to delineate areas where specific geologic and topographic conditions may constrain development. These maps are derived from surficial and bedrock geologic maps and from additional interpretation of aerial photographs and topographic maps. At least six factors bearing on land use decisions will appear on most of these maps: (1) near-surface coal that can be strip-mined economically, (2) subsurface or surface source of aggregate (generally "clinker"), (3) hard rock near the surface, (4) potentially unstable slopes, (5) high water table and flooding risk, and (6) difficult access for vehicles. Each of these factors will be represented by a single-digit number, one through six, in the areas where it appears on the map. Thus the user interested in a given site can consult the map to see what numbers and, therefore, what possible constraints appear at the site. Or the user can color all areas having a given number to produce a map showing the distribution of that constraint.

A11 maps and explanatory material produced in this project are designed to be useful to the nongeologist.

\section{GEOCHEMICAL BASELINES}

$$
\text { By }
$$

Richard J. Ebens, Ronald R. Tidba11,

$$
\text { James A. Erdman, }
$$

Gerald L. Feder, and Walter E. Dean

Three years of work in the coal-bearing regions of the Northern Great Plains and Rocky Mountains have resulted in the provisional establishment of regionally useful geochemical baselines in 17 near-surface ("1andscape") materials. These results are based on work from 25 independent field studies of regional scope in the Powder River Basin, the Northern Great Plains, and the oil shale region of Colorado, Wyoming, and Utah. Baselines have been established for as many as 45 elements in rocks, soils, sediments, waters, and plants, although the element suite varies from material to material and only partial data are currently available from many of the studies (U.S. Geological Survey, 1976).

Materials studied in the Powder River Basin include sandstone and shale of the Fort Union Formation; surface and subsurface soil; 
sediments of the Powder River; and sagebrush, lichen, and grass. Rocks of the Fort Union, surface and subsurface soil, and stream sediments also were collected in the Northern Great Plains, as were wheat and shallow ground water. In the oil shale region, soils were collected from Colorado, stream sediments from Colorado and Utah, and sagebrush from Wyoming.

Adjuncts to this regional work have included attempts to measure geochemical change in landscapes disturbed by activities related to energy production. Examination of the geochemistry of spoil material at eight stripmined areas (both reclaimed and abandoned) in the Northern Great Plains revealed that the average concentration of a number of elements (including $\mathrm{F}, \mathrm{Hg}, \mathrm{U}, \mathrm{Li}$, and $\mathrm{Th}$ ) at one or more of the mined areas that were studied nearly equals or exceeds the probable maximum concentration expected in nearby native surface soil. The geochemical impact observed on vegetation growing on mined spoils includes altered $\mathrm{Cu} / \mathrm{Mo}$ ratios in sweetclover (the observed average ratio was two, compared to an optimum for forage of seven or more) and increased concentrations of $\mathrm{Cd}$, Co, F, U, and $\mathrm{Zn}$ in wheatgrass when compared to controls. Vegetation impacts around coal-fired electricgenerating plants include elevated concentrations of $\mathrm{Se}$ in both sagebrush and lichen near the Dave Johnston powerplant (Wyoming) and in grass near the Four Corners powerplant (New Mexico). In addition, $\mathrm{Sr}$ was elevated in all three vegetation types and $\mathrm{Fe}$ was elevated in lichen and grass at sampling sites close to the plants.

Additional findings of interest include (1) the demonstration that $\mathrm{As}, \mathrm{Hg}$, and $\mathrm{Se}$ (three elements commonly viewed as among the most hazardous of the trace metals) tend to occur in in situ oil shale in concentrations about five times that found in surface soils of the surrounding region, (2) the discovery of apparently natural levels of $F$ and gross alpha radiation in shallow ground water of the Northern Great Plains that exceed current Environmental Protection Agency standards for safe drinking; and (3) weak, but generally significant differences in trace-element levels between soils north and south of the glaciation boundary in North Dakota and Montana. In order to better assess potential health hazards that might result from a geochemical disturbance of the natural landscape, a synopsis of doseresponse relations reported in the literature has been compiled.

ENERGY LANDS MAPPING IN THE NORTHWEST POWDER RIVER BASIN, WYOMING By

S. P. Kanizay

Geologic mapping of the Buffalo-Sheridan, Wyo., corridor at a scale of 1:50,000 was undertaken in FY 1976. A preliminary geologic map of the Buffalo area, northwest Powder River Basin, Wyo., has been published (Kanizay and others, 1976). The Sheridan area is being mapped in FY 1977. Each map comprises about $1,684 \mathrm{~km}^{2}$. The maps are intended to serve as bases for regional interpretive maps showing -engineering geologic conditions.

Detailed engineering geologic maps at scales of $1: 24,000$ or larger are being prepared for specific areas that may be impacted by energy development or that will yield geologic information for broad regional geotechnical studies. The Big Horn 7 1/2-minute quadrangle was published (Ebaugh, 1976), and field mapping for the Buffalo $71 / 2$-minute quadrangle is complete.

\section{LANDSLIDE MAPPING AND SLOPE-STABILITY}

ANALYSIS IN THE BIG HORN QUADRANGLE, SHERIDAN COUNTY, WYOMING

By

$$
\text { Wa1ter F. Ebaugh }
$$

Extensive lands1ide deposits (Chleborad and others, 1976) are important in planning industrial and residential construction that will accompany development of coal resources in the Buffalo-Sheridan area, Wyoming. The Big Horn quadrangle, located $7 \mathrm{~km}$ south of Sheridan, is an area in which future urban growth is planned. This study includes mapping of landslides and a drilling program to measure the geotechnical properties of material involved in a landslide typical of those in the area.

The 172 landslide deposits that were mapped cover only 1 percent of the Big Horn quadrangle area, but that 1 percent is in an area deemed likly for development. Eight-two percent of these deposits (74 percent by area) occur on slopes of greater than 25 percent $\left(14^{\circ}\right)$. Eighty-five percent of the landslides (90 percent by area) occur on east-facing slopes. Thirty-eight percent of the landslides ( 41 percent by area) cross coal or carbonaceous zones in the bedrock, and 55 percent occur on slopes capped by alluvial sand and gravel. Alluvium and carbonaceous bedrock and coal are major aquifers in the Big Horn quadrangle and are believed to contribute ground water to slopes, thereby increasing the weight of the surficial mass and contributing intergranular buoyancy to the materials.

A landslide in the Wasatch Formation on the Springer Ranch (Lowry and Cummings, 1966, p1. 1) was drilled, sampled, and instrumented ( $\mathrm{fig}, 11$ ) to obtain information about the geometry, the physical properties of materials, and the nature of movement of the landslide. A geotechnical 


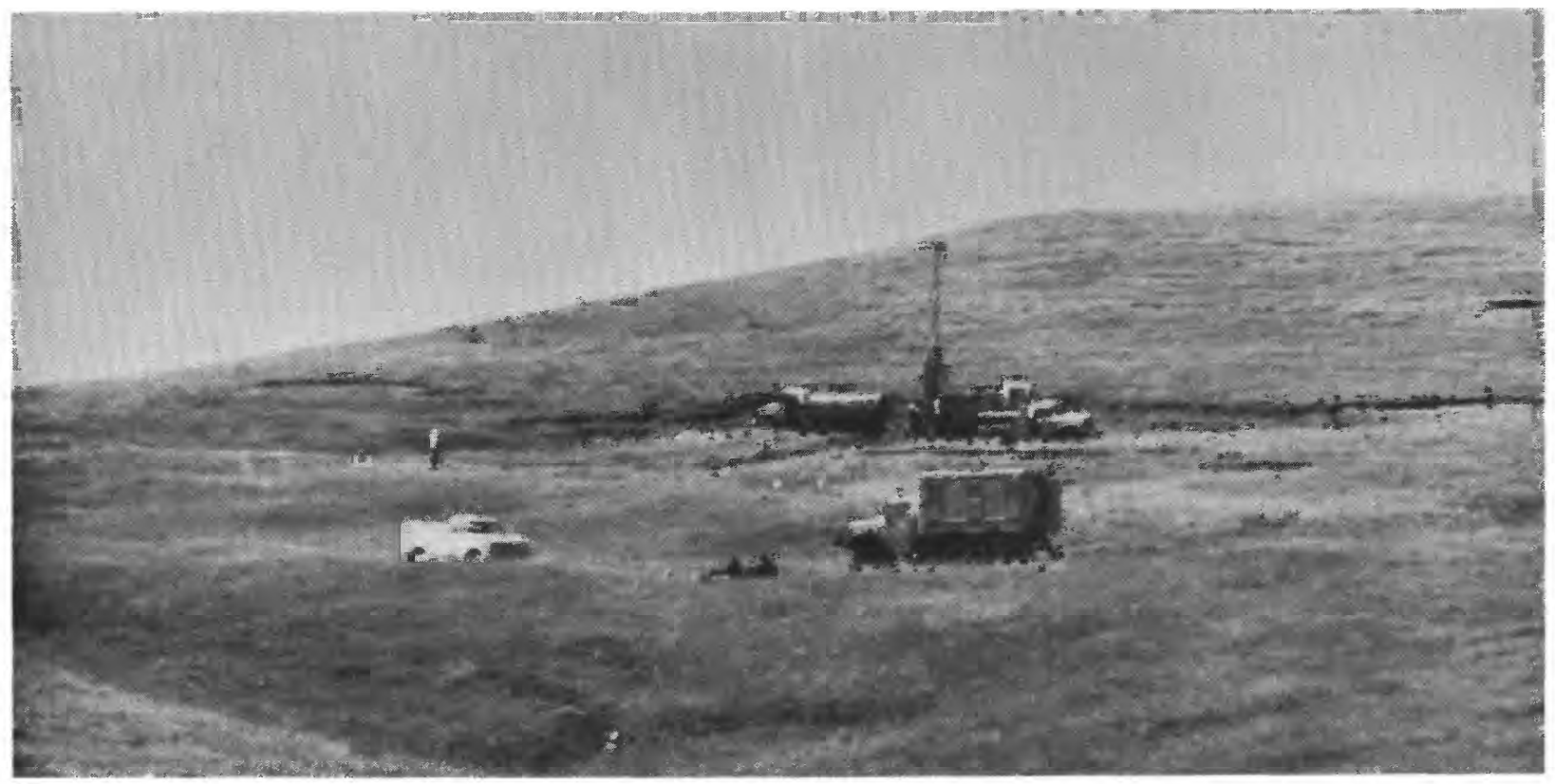

Figure 11.--U.S. Geological Survey drilling crew sampling and installing instrumentation in a landslide in the Wasatch Formation on the Springer Ranch in the Big Horn 7 1/2-minute quadrangle, Wyo. The slide scarp is beyond the water truck and drill truck. Although the slope is gentle, the surface on the slide is hummocky and contains several small berms.

profile of the slide mass was obtained from observations and measurements of color, grain size, density, pocket-penetrometer strength indices, moisture content, and Atterberg limits from samples collected from three boreholes spaced along the centerline of the slide. The geotechnical profile reveals a two-layer system of colluvium overlying bedrock, with the landslide failure surface occurring at the colluvium-bedrock interface.

Triaxial testing of undisturbed samples from the landslide will yield strength and stiffness values applicable to slope-stability analysis.

Information obtained from the analysis will be combined with other data such as occurrence, slope aspect, natural moisture, and thickness of unconsolidated or poorly consolidated material. These integrated data then will be extrapolated throughout the Big Horn quadrangle to prepare a map of relative susceptibility of various geologic units to slope failure.

\section{ENGINEERING GEOPHYSICAL INVESTIGATIONS}

IN THE POWDER RIVER BASIN, WYOMING AND MONTANA

By

Carter H. Miller

The historical seismicity of the Powder River Basin indicated by both earthquake intensities (felt by humans) and earthquake magnitudes (instrumentally measured), has been compiled from data files of the National Geophysical and Solar-Terrestrial Data Center, the U.S. Geological Survey, and LASA (Large Aperture Seismic Array).

These data indicate that the area is historically seismically quiet. From about 1870 to 1976, the northern part of the basin was a zone of few earthquakes of low magnitudes and intensities, and it is classed as an area of no damage to minor damage.

Several low-magnitude earthquakes, however, have been recorded in the last few years by LASA (Dary1 Gress and Robert Matkin, written commun., 1976) and local U.S. Geological Survey monitoring (F. W. Osterwald and C. R. Dunrud, written commun., 1976).

Many chemical explosions are detonated during coal strip mining; they are routinely recorded by LASA and sometimes by local U.S. Geological Survey monitoring. of interest to future mining and urban development are many aftershocks, which apparently are similar to rock bursts, that occur in the strip mines following the explosions.

Many landslides in the Powder River Basin occur on slopes underlain by sand-shale sequences. These slides cause damage to highways and agricultural land, and some 
construction may inadvertently be sited on a potential slide.

One landslide in the basin was chosen for detailed study, Thirteen seismic-refraction compressional-wave and two shear-wave profiles were run on the slide. The objective was to determine the buried configuration of the slide and compare the shear strength of materials in the slide with that of the nearby hillslope on which failure had not occurred. Preliminary interpretation indicates that a "weathered" lowvelocity layer overlies a "nonweathered" highvelocity layer. The low-velocity layer is about 3.1-6.2 $\mathrm{m}$ thick, and apparently all slide failure occurs in it. The shear strength of the low-velocity layer is about 5-10 times less than that of the underlying high-velocity layer.

A study was undertaken by R. A. Farrow, C. H. Miller, and A. L. Ramierz (USGS) to relate certain engineering properties of the quality and minability of clinkers from burned coal beds and to develop geophysical methods useful in exploring for buried clinkers. An outcrop of clinker was measured for engineering, magnetic, and seismic properties.

A magnetic profile was run with a hand-held magnetometer over the contact of clinker with unburned clastic rocks. A distinct anomaly of at least 800 gammas was measured, and the position of the contact could be discerned within about $6,2 \mathrm{~m}$.

Magnetic and seismic surveys were also run on a line parallel to the outcrop; and Schmidt hammer, color, and magnetic hand-sample tests were run at the outcrop. Laboratory tests included drillability, sonic, density, and porosity tests. Preliminary results show that many laboratory tests are difficult to perform, because the clinkers are highly fractured and porous. In situ seismic compressional and shear-wave data and some laboratory data show that the clinkers are a low-strength rock, and care should be used in siting heavy structures on them or in using them as critical wearing surfaces. Seismic tests showed that all clinkers tested could be easily quarried using a D-9 tractor having No. 9 teeth. Most quarried clinkers in the basin are loosened with much lighter equipment, but sometimes overlying clastic rocks must be loosened by explosives.

Two holes in the Powder River Basin were cored to depths of more than $122 \mathrm{~m}$, and geophysical logs were run (R. A. Farrow, U.S. Geological Survey, written commun., 1976). Interpretation of the geophysical logs has progressed to partial interpretation of the sonic and electric logs.

The sonic logs show a velocity gradient caused by overburden stress of about $1.07 \mathrm{~m} / \mathrm{sec}$ per vertical $0.305 \mathrm{~m}(3.5 \mathrm{ft} / \mathrm{sec}$ per vertical foot) of depth. These logs also will be interpreted for certain physical properties and rock strengths associated with the design of underground openings.

Resistivities and ash content of about 50 core samples of coal have been measured in the laboratory, and these will be compared with the electric logs. There may be a correlation between ash content, which is contributed mainly by clay impurities in the coal, and resistivity of the coal.

Magnetic, gravity, electromagnetic, and seismic-refraction surface geophysical surveys were carried out over the grid, Standard data corrections were begun, and, as of January 1977, about two thirds of the data had been reduced and interpreted. Preliminary and partial results indicate that contour maps of the magnetic, gravity, and electromagnetic data show trends of the underground coal mine but probably are not individually diagnostic. Preliminary seismic data reduction indicates that seismic methods may help in locating the underground openings. Surface detection of subsurface voids long has been a problem in geophysics. A series of experiments were designed for this project to try to find a solution. First, a system of underground coal mines in the eastern Powder River Basin was selected as an experimental site. A $1930^{\circ} \mathrm{s}$ map of the underground workings was used to lay out outlines of the workings on the surface, A grid then was established so as to cross the boundary between mined and unmined areas.

\section{REGIONAL GEOTECHNICAL INVESTIGATIONS}

By

\section{Alan F. Chleborad}

A preliminary study of geotechnical characteristics of the Fort Union and Wasatch Formations near Sheridan, Wyo., indicates that the following natural or manmade conditions are dominant factors contributing to landsliding in the area: (1) much of the bedrock and colluvial materials are fine grained, rich in clay, and plastic; (2) terrace gravels, and sandstone and carbonaceous aquifers deliver water to unstable slopes; (3) steep slopes commonly occur at the outcrops of these aquifers; and (4) moisture is concentrated on some slopes as a result of drifted snow from heavy spring storms, the gentle easterly dip of the beds (aquifers), and irrigation by local ranchers.

A statistical study of the relationship between slope aspect and landsliding occurrence for 558 landslides shows that 82 percent of the slides are on easterly facing hillsides and most 


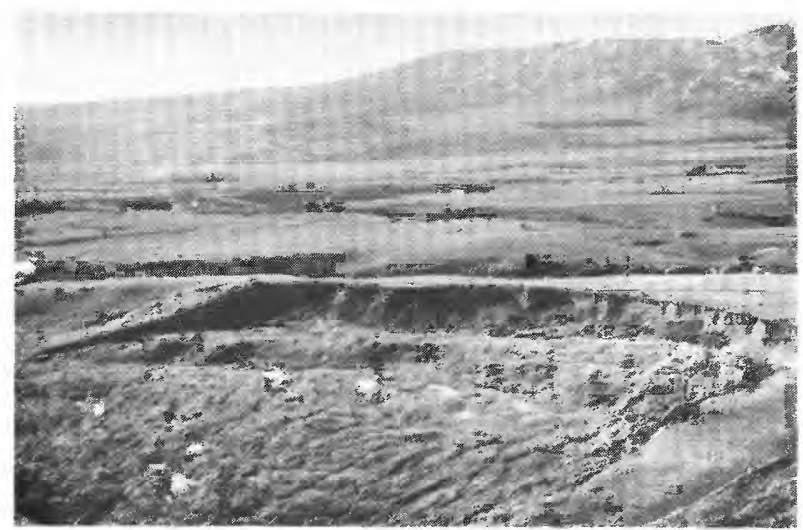

Figure 12.--Aerial oblique photograph of a large landslide in the Fort Union Formation near Sheridan, Wyo. View westwrd.

are on northeasterly slopes. This preference may be accounted for by moisture concentrated by snowdrifts resulting from the prevailing northwest wind direction and from the slight easterly dip of the beds, which preferentially delivers water to easterly slopes (fig. 12).

Twenty-two landslides were randomly selected and profiled in detail. Statistical analysis of measured slope angles indicates a mean slope angle for the 22 slides of $14^{\circ}$, with a range of $10^{\circ}$ to $20^{\circ}$. The lesser slope angles are associated with slides on easterly slopes.

A landslide south of Sheridan in the Big Horn quadrangle was drilled and sampled. Preliminary analysis of core samples indicates a shallow failure zone (less than $6 \mathrm{~m}$ deep) involving weathered bedrock (Wasatch) and colluvial material. Piezometers were installed in this landslide, and several inclinometer boreholes were drilled to obtain information on pore-water pressure and slide movement.

A report on landsliding in the Sheridan area (Chleborad and others, 1976) was enthusiastically received by the Sheridan County Planning Commission in a July 1976 meeting in Sheridan. The Commission felt that the information in the report was badly needed and would be a valuable tool in future planning in Sheridan County.

GEOTECHNICAL PROPERTIES OF THE

FORT UNION AND WASATCH FORMATIONS

By

Edward E. McGregor, Richard A. Farrow, and Harold W. Olsen

Testing of rocks from the Fort Union and Wasatch Formations in the Powder River Basin for geotechnical properties is an ongoing study in the USGS. The study was begun in 1974 in cooperation with USBR (U.S. Bureau of Reclamation) drilling projects for BLM (U.S. Bureau of Land Management). Physical properties tests also were performed in the field at Recluse, Wyo., during 1975 and 1976, in cooperation with the Coal Resources Branch of USGS.

McGregor (1975) described the results of selected physical properties tests from two USBR-BLM drill holes near Ashland, Mont. Farrow (1976) described the results of a core-hole testing program at Buffalo, Wyo. Similar programs are underway at Sheridan and Acme, Wyo. Physical-properties test data from a USBR-BLM drilling program near Bear Creek in the West Moorhead coal field, Montana, and from Recluse, Wyo., also are being evaluated in FY 1977. Locations of all the drill sites are shown in figure 13 .

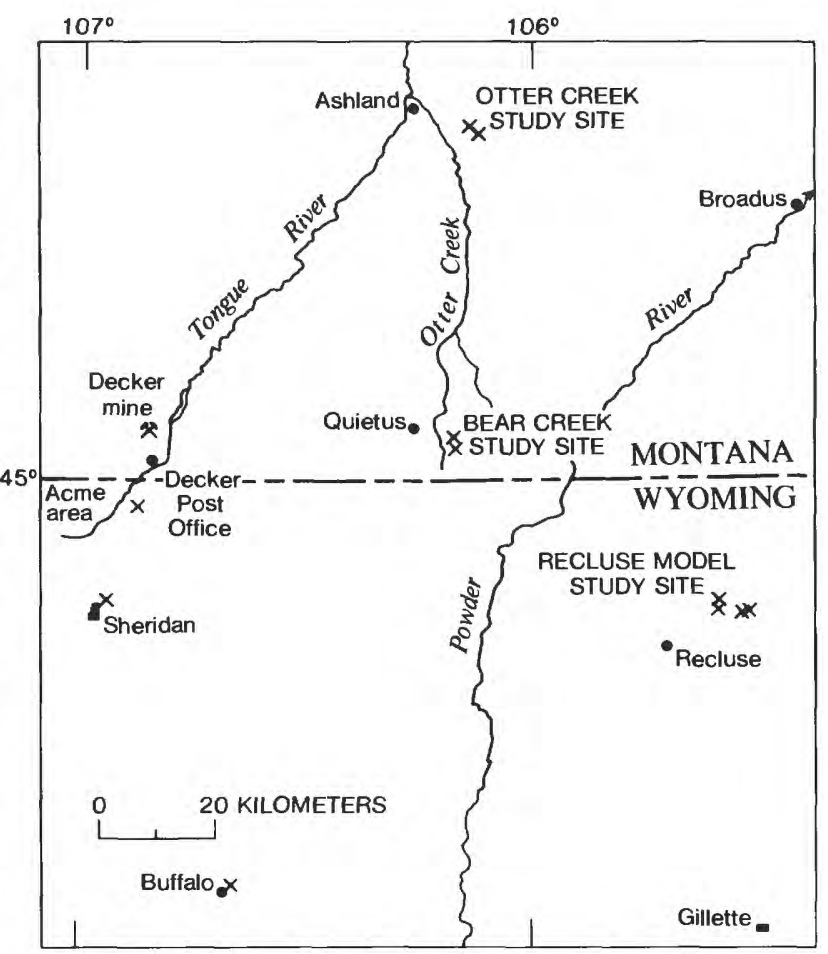

Figure 13.--Index map of northern Powder River Basin, showing locations of drill holes (x) from which cores were tested. Geophysical logs also were obtained from drill holes in Buffalo and Sheridan, Wyo.

Geotechnical data from these drilling programs are intended to serve the public need for information on geologic conditions that influence coal mining operations in the Powder River Basin. Of particular interest are the roof and floor rocks (strata above and below 
major coal beds) because of their importance to both underground and surface mining. The data are intended for use by government agencies and public groups involved in planning, evaluation, and other decisions regarding coal mining; the data also should be useful to the coal-mining industry. An example of the information in the published reports is given in figure 14 (Farrow, 1976).

The work in late 1976 consisted primarily of both field and laboratory measurements on cores from drill sites located near Buffalo, Sheridan, Acme, and Recluse, Wyo. A regional interpretation of the geotechnical conditions of rocks in the Powder River Basin is planned.

Physical-properties tests on samples of the Fort Union Formation in the northern and western Powder River Basin show that, with few exceptions, the rocks of the Fort Union Formation are so weak that they cannot be tested as rocks but must be considered as strong soils. The rocks were tested at natural-moisture conditions; and, in general, the siltstones and shales behave plastically at high-natural moisture conditions. Sandstone and silty sandstone with natural moisture either are plastic or crumble when removed from a core barre1. Dehydrated (surface case-hardening) surface exposures are cemented and hard, and do not reflect the character of the rock at depth. The rocks have very low tensile and compressive strengths (as determined by testing), which suggests the need for very careful design of slopes, mine faces, and pit floors.

The Wasatch Formation at Buffalo, Wyo., was cored to a depth of $133 \mathrm{~m}$ (Farrow, 1976). Five lithologic units were recognized from sample testing and examination of geophysical logs. A poorly cemented sandy unit largely barren of coal, but containing water under an artesian head, occurs from the surface to a depth of 28 $\mathrm{m}$. An upper sequence of coal, claystone, and shale occurs in the interval from 28 to $45 \mathrm{~m}$ and is underlain by about $11 \mathrm{~m}$ of sandstone and claystone; a second coal unit extends from 56 to $100 \mathrm{~m}$ in depth. Below the second coal unit is a partly fossiliferous claystone and sandstone

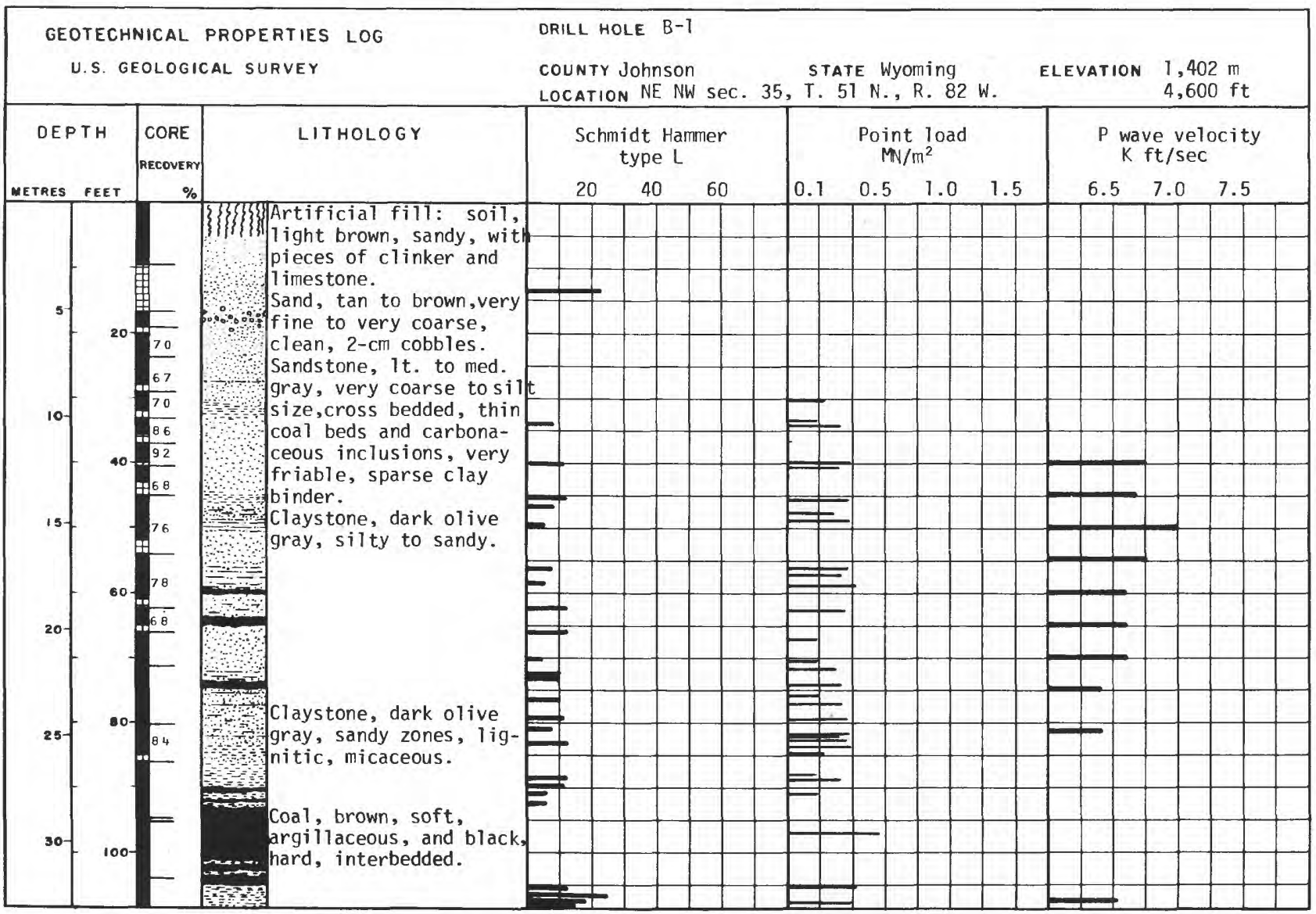

Figure 14.--Typical geotechnica1-properties $10 \mathrm{~g}$ of drill hole B-1, Buffalo, Wyo. (modified from Farrow, 1976). MN $/ \mathrm{m}^{2}$, miliinewton $/ \mathrm{m}^{2} ; \mathrm{K} \mathrm{ft} / \mathrm{sec}$, thousands of feet per second. 
unit with only thin coal beds extending to the total depth of $133 \mathrm{~m}$. Test results ( $\mathrm{fig}$. 14) show that the coal is the most structurally competent material present. Sandstones and claystones, even at depth, are weakly cemented and almost without cohesive strength. Artesian water flow from the weak sandstone near the surface may cause serious stability problems for highwalls of open-pit mines in the unit. Disturbance of artesian pressure, which possibly could be caused by surface mining, would affect local domestic water wells for an unknown period of time.

\section{COAL MINE DEFORMATION,} WESTERN POWDER RIVER BASIN

\section{By}

\section{Richard Dunrud}

This element of the engineering geologic studies, Powder River Basin Project, focuses on the engineering geologic factors that control the response of bedrock and surficial material to past large-scale mining activities and on an overview of selected present surface mining operations. Results of this study, together with results of other elements of the project, will provide a knowledge base from which to determine the relative merits of surface mining and underground mining in dominantly weak rocks of the Fort Union and Wasatch Formations. Information on subsidence effects on rocks of the Mesaverde Group (Upper Cretaceous) in deeper overburden in Utah and Colorado has been published (Dunrud, 1976; Sargent and Hansen, 1976).

Results to date show that the effects of past underground room-and pillar mining in a 91$\mathrm{km}^{2}$ area, 10-16 $\mathrm{km}$ north of Sheridan, Wyo., were more damaging to the environment and less productive than those of current surface mining operations. Surface subsidence features, such as depressions, pits, tension cracks, and compression bulges, as well as coal mine fires, are a continuing threat to the environment and commonly decrease values of land above underground mines that were abandoned 25 to 50 years ago (figs. 15, 16).

Many abandoned mines have caught fire and
are burning out of control (fig, 15). Apparently the processes of oxidation and hydration, resulting from the introduction of air and water into the abandoned mine workings, raised the temperature of the coal to the level of spontaneous combustion. Burning then produced more underground voids, which in turn provided more air to the fire and continually maintained the burning on a broadening front. A fire also was observed on the highwall of an abandoned surface mine in the study area. Coal mine fires are a serious environmental hazard, as well as a waste of energy resources.
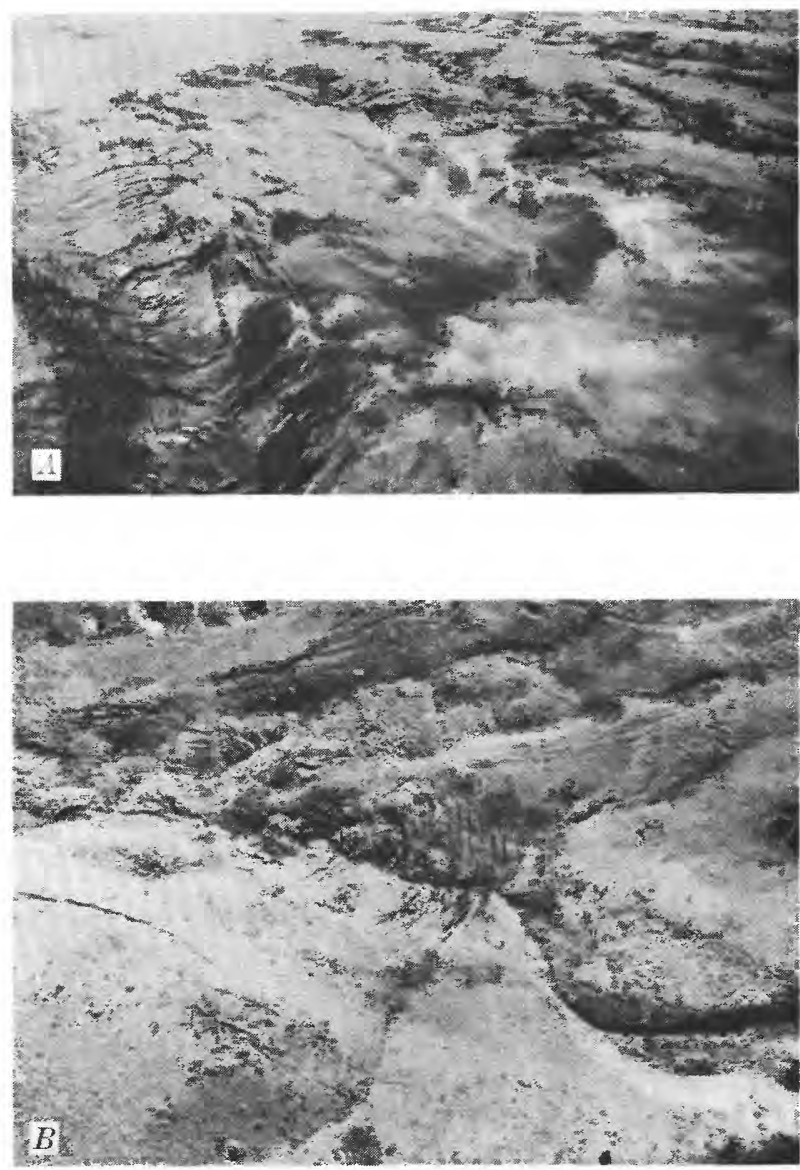

Figure 15.--Effects of past underground roomand-pillar coal-mining activities in the western Powder River Basin about $20 \mathrm{~km}$ north of Sheridan, Wyo. $A$, oblique aerial view of pit in which an underground coalmine fire has breached the surface; note concentric cracks within "fire pit" and cracks at the margin of depression surrounding "fire pit." Pits in left background are located above individual rooms of abandoned coal mine; overburden is an estimated $15-23 \mathrm{~m}$ thick. $\underline{B}$, westward oblique aerial view of the effects of a coal mine fire. Pits above individual mine openings can be seen in left foreground. Steam and noxious gases issuing from subsidence pits and cracks can cause severe air pollution. Photographs by C. R. Dunrud.

Past underground mining extracted only 1020 percent of the coal, because the coal beds were too thick to be mined completely by thencurrent underground methods. Coal recovery commonly exceeds 90 percent (fig.16) on lands that are mined by surface methods and where the overburden rocks are weak and less than $60 \mathrm{~m}$ thick. Also, these land areas can be restored to further use in a more practical manner than 


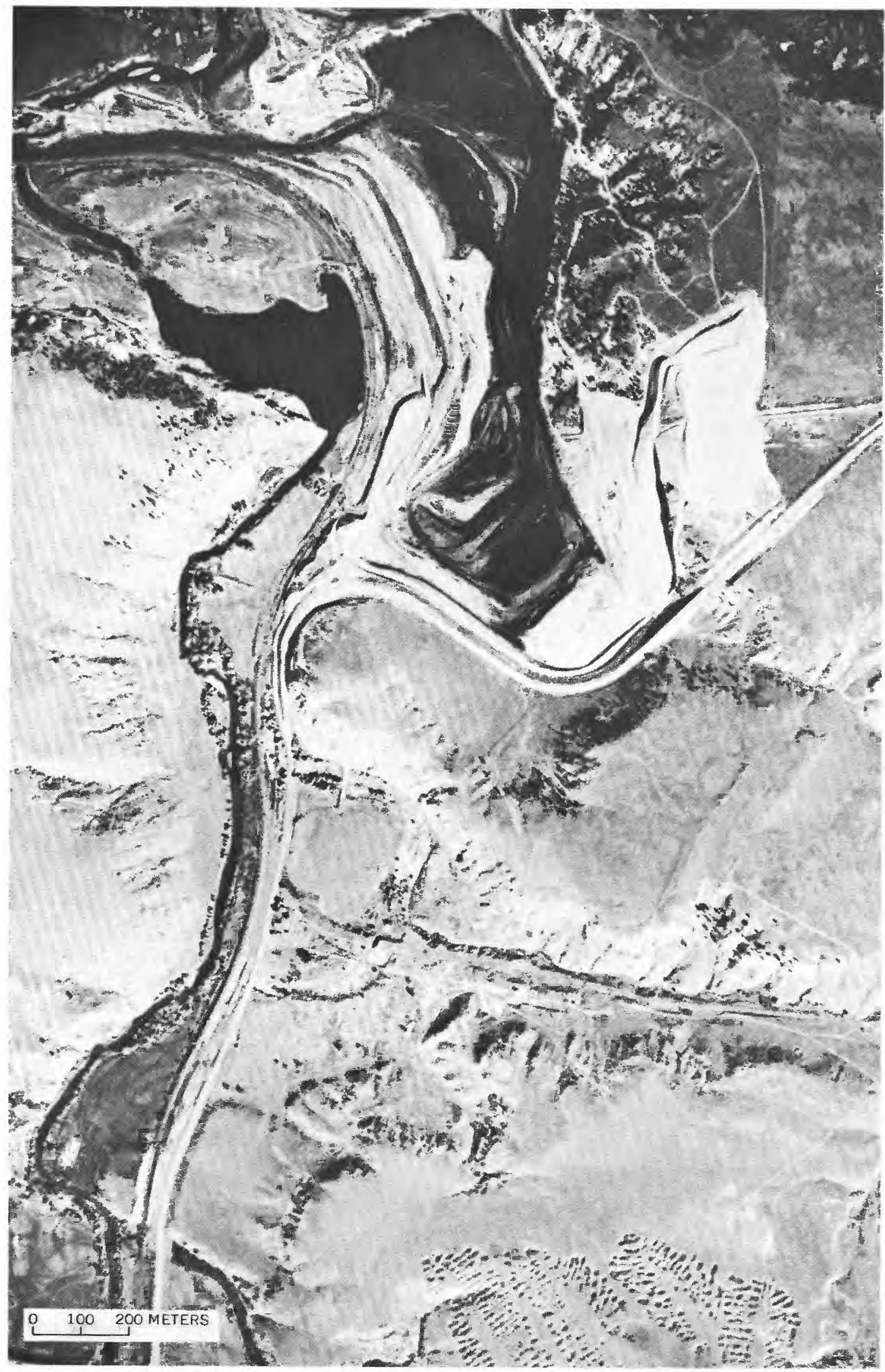


$\checkmark$ Figure 16.--Vertical aerial infra-red photograph showing the effects of past and present mining activities in an area about $10 \mathrm{~km}$ north of Sheridan, Wyo. Present-day surface-mining activities, located in the northern (top) part of picture, extract more than 90 percent of three coal beds having an aggregate thickness of $14-18 \mathrm{~m}$. The overburden is removed by cat and scraper, stored to the right of the pit, and hauled and graded in an area to the left of the pit. The graded and restored areas around part of the lobe are revegetated in sequence with the mining operation. The pit-and-trough topography in the southern part of the picture was caused by subsidence of the ground surface into individual room-and-pillar mine workings, driven in the early $1900^{\circ} \mathrm{s}, 8-46 \mathrm{~m}$ below the surface. The underground mining activities removed only an estimated 10-25 percent of the coal resource. Subsidence is currently active and a hazard to man and beast, even though the mines were abandoned 50-75 years ago.

land areas disturbed by underground mining operations. However, the highwalls should be graded to stable slopes to prevent landslides, and coal should be covered with enough incombustible material to minimize the chances for spontaneous ignition ( $f i g, 17$ ).

STABILITY OF HIGHWALLS IN SURFACE COAL MINES, WESTERN POWDER RIVER BASIN

By

William Z, Savage and William K. Smith

Field and laboratory investigations into the stability of highwalls in open-pit coal mines in the western Powder River Basin of Wyoming and Montana suggest that several factors influence highwall stability. Some of these factors are rebound of overconsolidated rocks, desiccation, water, orientation and spacing of fractures, and strength and deformation properties of the rocks and coal (fig.17).

The strength and deformation properties have been experimentally determined for rocks of the Tongue River Member of the Fort Union Formation (Paleocene). These properties, which include Young's moduli, cohesion, internal fraction angles, densities, and tensile strengths, are given in Lee, Smith, and Savage

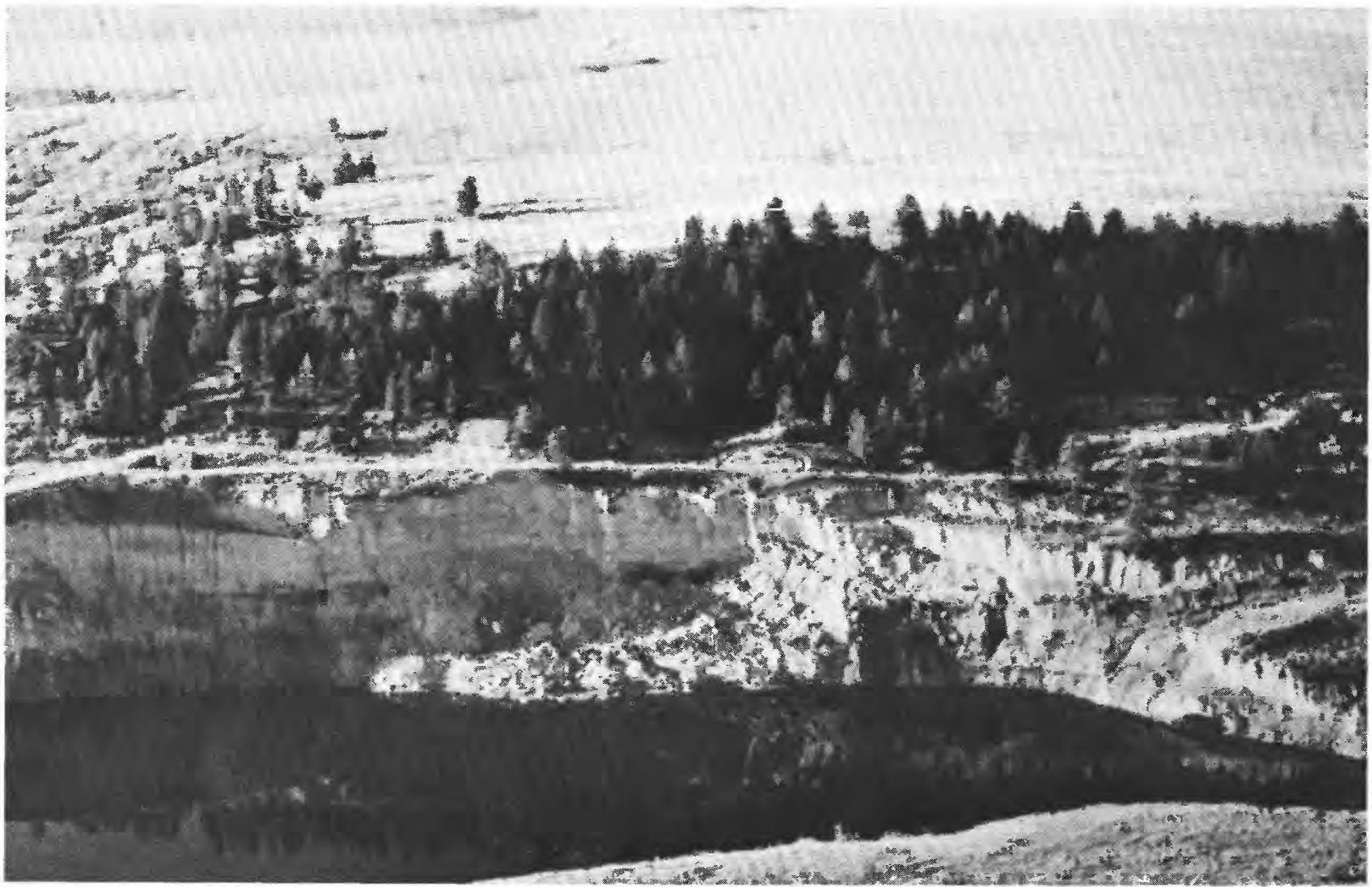

Figure 17.--Deteriorated highwall of a strip coal mine in Fort Union Formation $1.3 \mathrm{~km} \mathrm{north} \mathrm{of}$ Sheridan, Wyo., along Goose Creek. The mine was abandoned prior to 1968; the highwal1 is failing in a series of slumps resembling classic landslides. The coal at water level near right center has ignited spontaneously along one of the landslide slip surfaces. Photograph by F. W. Osterwald. 
(1976) and in Fahy and Smith (1976); the results of all laboratory and field investigations to date are also given.

The most critical factor appears to be the degradation of strength and deformation properties of highwall rocks with time after excavation. Factors of safety, calculated by the finite-element method for highwalls that have degraded, are in many cases lower than 1.0 . Because the highwalls do deteriorate and become progressively less stable with time, postmining failures are common and could be critical if mining were delayed and then resumed after a period of several months.

\section{QUATERNARY CHRONOLOGY IN}

\section{NORTHWEST COLORADO ENERGY LANDS}

By

\section{R. F. Madole}

Construction of the Quaternary chronology needed to evaluate the rates at which processes such as erosion, sedimentation, and mass movement operate in the craig region of northwest Colorado is progressing well. Pearlette ash in terrace deposits $122 \mathrm{~m}$ above the Little Snake River has been identified as type 0 . Hence, net denudation in this part of northwest Colorado during the past 600,000 years appears to have been twice as great as in the northern Colorado Piedmont east of the Front Range. However, the rate of dissection in these two regions during Holocene time apparently was comparable. This conclusion is based on the amount of dissection of parabolic dunes on the valley floor of the Little Snake River, dunes which are tentatively assigned to early or middle Holocene time on the basis of soilprofile development. Radiocarbon ages for a paleosol and for the remains of a hearth containing charred bones are expected to provide a minimum age for the dunes.

Work just east of the southeast corner of the Craig 2-degree quadrangle, done jointly with Professor E. E. Larson, University of Colorado, and R. G. Baker, University of Iowa, has demonstrated that paleomagnetic study of lacustrine rhythmites offers great promise for providing interregional correlation of Quaternary events. Rhythmites of the type studied are relatively common in mountainous portions of Colorado. In addition, radiocarbon ages obtained for sections of the rhythmites established that Pinedale Glaciation was at least close to its maximum in the Front Range by $21,180 \pm 2,360$ years ago (laboratory sample DIC $-57 \overline{4}$ ).

\section{ENVIRONMENTAL GEOLOGIC INVESTIGATIONS IN THE KAIPAROWITS PLATEAU}

By

\section{K. A. Sargent}

As the geologic map of the coal area nears completion, several aspects of the relation between structure and erosional history become apparent. Early workers concluded that the main period of folding in the Colorado Plateau was near and following the end of Late Cretaceous time. In earliest Tertiary time an interior drainage basin developed chiefly north of the Kaiparowits Plateau. At the south end of the basin, coarse gravels and mudstones, and later, in Eocene (Wasatch) time, freshwater limestones and sandstones were deposited. Large-scale sedimentation ceased at the onset of regional uplift and was followed by volcanism and normal faulting. By early Miocene time (about 20 million years ago), volcanism ceased and much of the extent of the Escalante and Paria Rivers (fig. 18) had been superimposed across the structural grain. Their headwaters were near the southern extent of the lava field. As regional uplift continued, the tributaries developed an extensive pediment and terrace network. Some surfaces cut on various levels of Mesozoic rock still exist in the upper reaches of the Escalante and Paria Rivers. The highest surfaces above the Escalante River are capped with a deposit of large rounded basalt boulders derived from flows on the Aquarius Plateau, a few kilometers to the north. These pediment surfaces are about $550-730 \mathrm{~m}$ above the presently entrenched Escalante River bed at elevations between 2,260 and 2,2440 m, above all topographic barriers except the Aquarius Plateau. Other tributaries to the colorado River are chiefly consequential streams. Between the Escalante and Paria Rivers, large quantities of Upper Cretaceous coal are preserved in the downwarp under the Kaiparowits Plateau. Geologic structure and erosional history will influence the development of this remote area. Access is difficult because of rugged topography, landslide and rockfall hazards, and steep grades. Thickness of overburden, local steep dips, lateral rock variations, zones of burned coal, and the lenticular nature of coal deposits will limit the amount of coal recovered.

\section{WATER RESOURCES INVESTIGATIONS IN THE KAIPAROWITS \\ COAL BASIN AREA, UTAH}

By

Don Price

The water resources studies in the Kaiparowits coal basin area, Utah, are based largely on file data collected over the years by the USGS in cooperation with other Federal 
agencies and the Utah Department of Natural Resources, Two maps showing general availability and general chemical quality of ground water in the area have been published (Price, 1976a,b). Two additional maps will show runoff, streamflow characteristics, and surfacewater quality in the area.

The Kaiparowits coal basin area is arid to semiarid. Normal annual precipitation ranges from less than $152 \mathrm{~mm}$ along the shore of Lake Powell to about $635 \mathrm{~mm}$ in the headwater area of the Escalante River (fig. 18). Mean annual runoff ranges from much less than $25 \mathrm{~mm}$ throughout most of the area to about $254 \mathrm{~mm}$ in the headwaters of the Escalante River. Most runoff occurs during melting of the winter snowpack, but significant runoff also occurs as cloudburst floods during summer cloudburst activity.

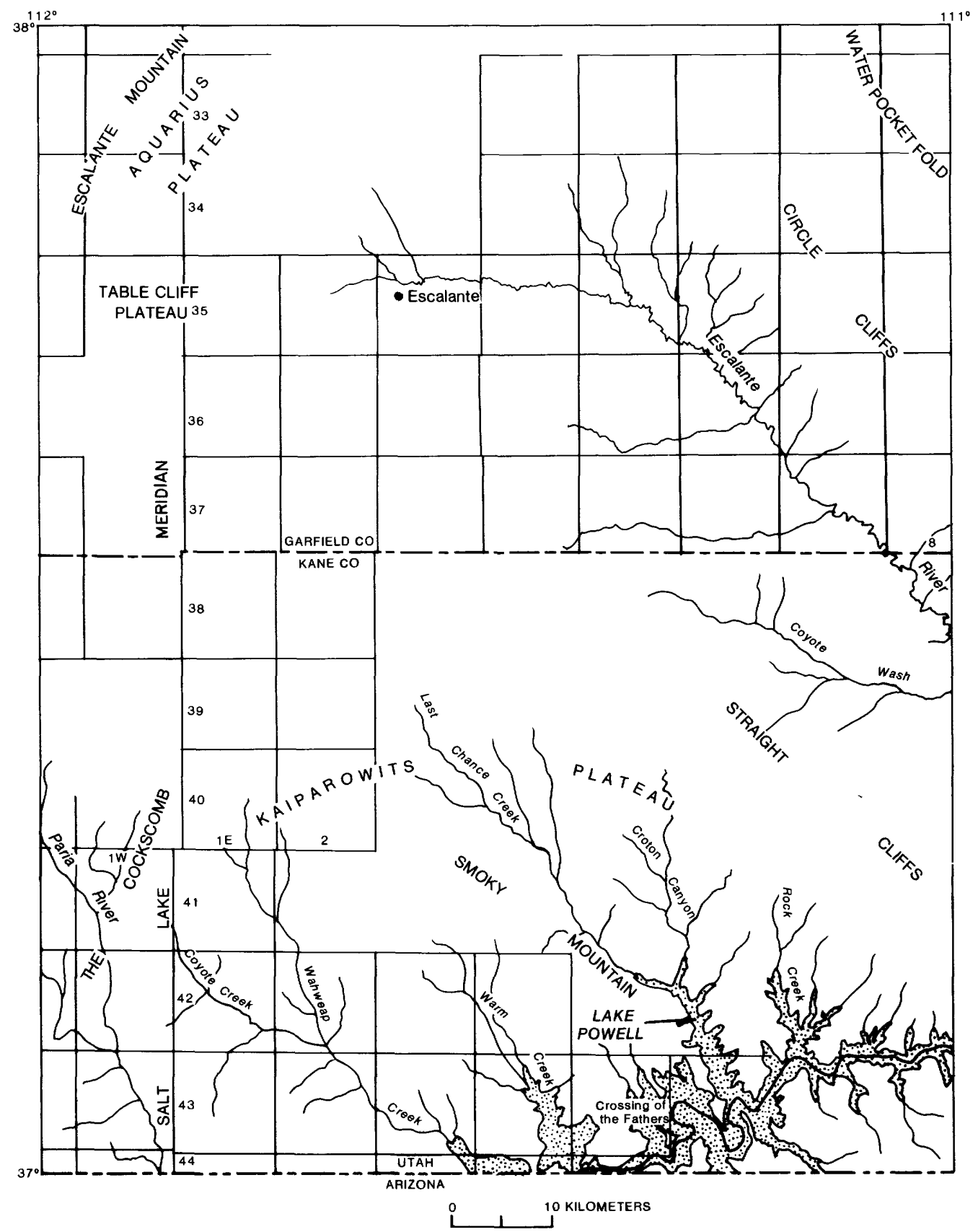

Figure 18.--Map of geography and principal drainage system of the Kaiparowits coal basin area, Utah. Modified from U.S. Geological Survey 1:500,000 map of Utah, 1959. 
Concentrations of dissolved solids in runoff range from less than 200 to about 1,800 $\mathrm{mg} / \mathrm{L}$ (milligrams per 1iter) during high flow periods, and from about 250 to more than 3,000 $\mathrm{mg} / \mathrm{L}$ during low flow periods. Concentrations of dissolved solids in the water in Lake Powell average about $550 \mathrm{mg} / \mathrm{L}$.

Most of the ground water available for development in the area occurs in sedimentary rocks consisting chiefly of interbedded strata of sandstone, siltstone, shale, conglomerate, and limestone. The most productive aquifers are in the Navajo Sandstone (Triassic? and Jurassic) and are capable of yielding 6.3 to $63 \mathrm{~L} / \mathrm{sec}$ of fresh to slightly saline water to wells. The Navajo Sandstone crops out around the margins of the Kaiparowits Plateau, but is overlain by 220 to $610 \mathrm{~m}$ of younger strata beneath the plateau.

Concentration of dissolved solids from ground water in the Kaiparowits coal basin ranges from less than 500 to about $1,000 \mathrm{mg} / \mathrm{L}$, except beneath the Kaiparowits Plateau and in the Waterpocket Fold area (fig. 18) where concentrations range from about 1,000 to more than $3,000 \mathrm{mg} / \mathrm{L} 1$ ocal1y.

Not considering existing water rights, the best potential sources of water for development of the area's coal resources are Lake Powe11, which has a maximum usable storage capacity of about $34,500 \mathrm{hm}^{3}$; the Escalante River, which has an average annual discharge below Escalante of about $15.4 \mathrm{hm}^{3}$ (based on 19 years of records); and aquifers in the Navajo Sandstone.

THE IMPROVEMENT OF AVAILABLE

VOID CAPACITY OF SOILS ON MINE SPOILS IN ARID AND SEMIARID REGIONS

By

B. E. Munson, University of Denver

Investigations are beginning into a means of improving the capacity of soils to transmit and store moisture at depth. This method could aid rehabilitation (and irrigation) of stripmined areas in arid and semiarid regions. The feasibility of such a method is based on shrinkswell properties of soils.

Investigations are being carried out in the coal fields in Routt, Moffat, Jackson, and Fremont Counties, Colo. Spoils of recent age can be found in these fields. Sites were selected from coal fields on the basis of soil type (texture). Four plots will be established on each site, each of which will receive a different number of applications of irrigation waters (one to four). A soil sample will be taken from each plot after it has received the designated number of applications.
Subsequent laboratory analysis will determine the VMC (Void Moisture Capacity), or quantity of water required to fill voids to capacity, and the (Moisture Retention Capability) MRC, or quantity of moisture retained and absorbed by soil-particle surfaces in the form of multimolecular layers, for each sample. The quantity VMC minus MRC will be determined for each sample and will be referred to as AVC (Available Void Capacity). This is defined as "free" moisture, or that moisture available for use by plants. All above quantities will be expressed in grams of moisture per gram of dry weight.

Graphs of the quantity AVC versus the number of applications received should reveal the effect of irrigation on increasing voids in soils of different textures. Not only should this increase the ability of soils to store moisture for use by plants, but it could also conceivably increase the soil's infiltration capacity. By aiding in the establishment of a vegetal cover and increasing the infiltration capacity of soils, this method could provide an additional means of inhibiting erosion on mine spoils.

\section{LAND RESOURCES AND ENVIRONMENTAL IMPACT,}

EAST TEXAS LIGNITE BELT

By

John o. Maberry

Progress through 1976 by the Texas Bureau of Economic Geology in studies of the lignite belt can be roughly categorized into three major parts: (1) environmental geologic mapping, (2) water chemistry-hydrology studies, and (3) biologic studies. The study area is shown in figure 19.

The Wilcox Group-Carrizo Sand outcrop belt (fig. 19) from the Colorado River to the Trinity River was selected for environmental mapping for the following reasons: the Calvert Bluff Formation (Sharp, 1966) of the Wilcox Group (Eocene) is the major lignite-bearing unit; the area includes two active lignite strip mines, a probable 2.7 billion metric tons of near-surface (less than 60-m depth) lignite, and at least three mines planned to be in operation by about 1980; and three major aquifers have their recharge areas within the map area.

Environmental geologic mapping under the leadership of G. M. Wermund has been completed using 1:20,000-scale airphotos and extensive field checking of the entire pilot area, which includes all or part of sixty-three 7 1/2-minute quadrangles (approximately $8,000 \mathrm{~km}^{2}$ ). Twentythree different environmental units have been distinguished on the basis of substrate, soil, 


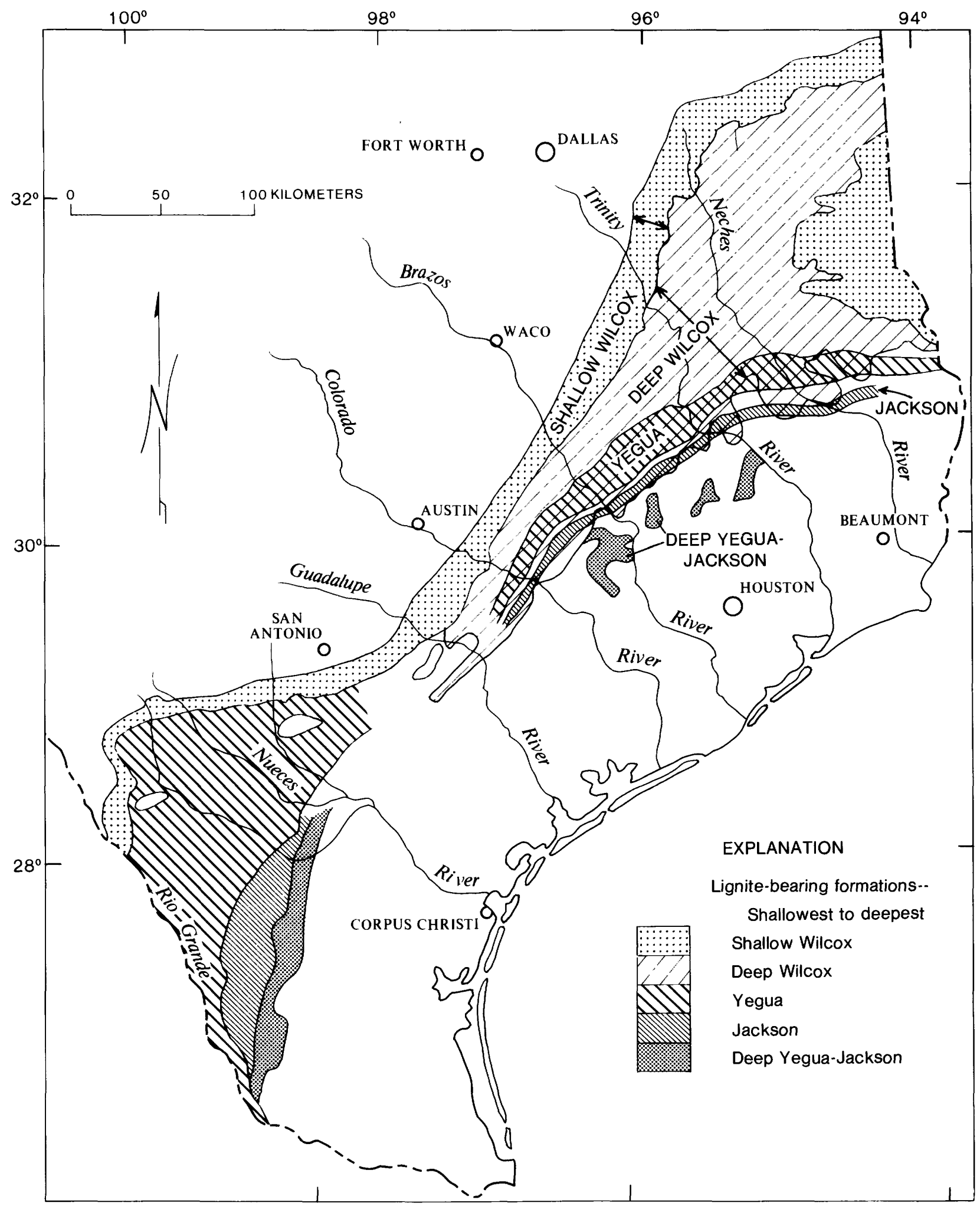

Figure 19. Map of eastern Texas, showing the extent of lignite-bearing formations. 
biologic assemblage, geomorphology, and geologic process. The mapping clearly identifies such problem areas for surface mining as aquifer recharge zones and flood-prone areas. It also provides an inventory of many other mineral resources (besides lignite), such as ironstone, sand and gravel, and other aggregate-type materials.

That the map units have a sound basis in terms of land use in the area has been assured by extensive discussions between Bureau scientists and personnel from the U.S. Soil Conservation Service and from the biology departments of the University of Texas and Stephen F. Austin University.

The bureau also tested the feasibility of continuing the mapping of the Wilcox-Carrizo outcrop belt into far northeast Texas and the Sabine uplift. Preliminary observation of $1: 80,000-s c a l e$ airphotos proves the feasibility of identifying and mapping units similar to those found in the pilot area.

Comparison of surface mapping with subsurface analysis of the Calvert Bluff Formation by W. R. Kaiser of the Bureau of Economic Geology, whose work demonstrates that the Calvert Bluff was deposited by a fluvial depositional system, shows excellent correlation between sands mapped at the surface and channel complexes extrapolated from the subsurface. Taken together, the two pieces of work clearly define the aquifer system within the Calvert Bluff, the aquifer most likely to receive mine discharge. With this information, mine discharge could possibly be routed away from the aquifer, or at least the best locations for wells to monitor water quality could be chosen.

Though not a goal of this project, the surface mapping, along with the subsurface information, could have been used as an excellent exploration tool had it existed during exploration phases. Lignite deposits are clearly in interchannel basins between major channel complexes.

Project personnel edited available waterquality data for the Wilcox-Carrizo aquifers using a Fortran program which evaluates the completeness and accuracy of the analyses. Usable analyses were then plotted and contoured by another computer program to determine three things: (1) baseline ground-water quality, with which to compare the effect of mine effluent; (2) a possible relationship between water chemistry and depositional system; and (3) the change in chemistry as water moves downdip through the various aquifers. The third determination can explain what chemical reactions are going on within the aquifer and what potential exists for "self-cleaning" of mine waters as they move downdip.
Items 1 and 3 together should be particularly useful in monitoring mine drainage and predicting its effect on overall water quality within an aquifer, Item 2 was relatively unsuccessful except in a gross sense--the Carrizo Sand can readily be distinguished from the more clayey Calvert Bluff Formation.

A second part of the water chemistry program has been the monitoring of surface-water quality. On a regular basis, the Bureau has collected water samples from medium-sized streams which primarily drain areas within the Wilcox outcrop. Sites that were monitored fall into three categories: (1) streams draining areas previously or currently mined, (2) streams draining areas that definitely will be mined in the future, and (3) streams that drain areas of similar geology to (1) and (2), but that do not contain sufficient lignite deposits ever to be mined. Samples are analyzed for basic water quality and selected trace elements.

Early results indicate that although mine drainage is altering the surface-water quality, any acid waters are being neutralized before they move very far downstream, An important adjunct to this study would be to determine exactly how and where neutralization is taking place. The program also provides careful control of background water quality, so that future effects of mine drainage can be accurately measured.

Several smaller projects involved the investigation of the hydrology of the area and of individual mine sites. These included a geomorphologic study of the drainage-density variation on surface exposures of the Wilcox Group and the relationship between drainage density, substrate composition, base flow, and mean annual flood. The study has shown a clear correlation between substrate and drainage density, which has been useful in environmental mapping.

A second hydrologic study examined the situation in which a mine pit intersects part of an aquifer. Assuming various geologic and hydrologic parameters, the study determined a range of ground-water discharges into the pit. It also illustrated the possibility that mine drainage may enter an aquifer without ever appearing at the surface.

Both studies have aided in evaluation of the hydrologic balance at a mine site and in monitoring the effect of mine drainage on ground water.

Biologic studies have also been conducted: (1) a study of the major floral assemblages in the lignite belt and the floral succession on unreclaimed spoil, and (2) a study of the effect 
of mine drainage on algal communities in streams draining mining areas.

The first study provides background information with which to evaluate the effectiveness of reclamation programs. Preliminary results from the second study indicate some differences in algal populations between waters that receive mine drainage and those that do not. The significance of these differences awaits careful evaluation of all the factors that could affect the algal variety. This study is being coordinated closely with the surface-water-quality monitoring program.

A measure of the initial success of this program is the interest shown by various groups in the methodology and application of environmental geologic mapping. The Texas Railroad Commission, the State agency charged with regulating surface mining, and several private companies active in lignite exploration have sought advice from the Bureau on identification of surface mining problems and planning of reclamation.

\section{REFERENCES CITED}

Chleborad, A. F., Nichols, T. C., Jr., and Ebaugh, W. F., 1976, A preliminary inventory, profile, and statistical evaluation of landslides in a region of projected urban development, Sheridan, Wyoming: U.S. Geol. Survey Open-File Rept. 76-571, 50 p., 26 figs,, 4 tables.

Dunrud, C. R., 1976, Some engineering geologic factors controlling coal mine subsidence in Utah and Colorado: U.S. Geol. Survey Prof. Paper 969, 39 p.

Ebaugh, W. F., 1976, Preliminary surficial and bedrock geologic map of the Big Horn quadrangle, Sheridan County, Wyoming: U.S. Geol. Survey Misc. Field Studies Map MF-801, $20 \mathrm{p}$.

Fahy, M. P., and Smith, W. K., 1976, Geotechnical properties of some upper Fort Union rocks from the Decker area, Big Horn County, Montana: U.S. Geol. Survey Open-File Rept. 76-596, $110 \mathrm{p}$.

Farrow, R. A., 1976, Preliminary report on the geotechnical properties of the Wasatch Formation of Buffalo, Wyoming: U.S. Geol. Survey Open-File Rept. 76-877, 78 p.

Fritts, H. C.., 1965, Tree-ring evidence for climatic changes in western North America: Monthly Weather Review, v. 93, no. 7, p. 421443.

Gumerman, G. J., and Euler, R. C., 1976, Black Mesa retrospect and prospect, in Gumerman, G.
J., and Euler, R. C., eds., Papers on the archaeology of Black Mesa, Arizona: Carbondale and Edwardsville, Illinois, Southern Illinois University Press, p. 162170 .

Haynes, C. V., Jr., 1968, Geochronology of late Quaternary alluvium, in Morrison, R. B., and Wright, H, E., Jr., eds., Means of correlation of Quaternary successions: Salt Lake City, Utah Univ. Press, p. 591-631.

Hevly, R. H., and Karlstrom, T. N. V., 1974, Southwest paleoclimate and continental correlations, in Karlstrom, T. N. V., and others, eds., The geology of northern Arizona with notes on archaeology and paleoclimate: Geol. Soc. America Field Guide, Vol. I; 27th Ann. Mtg. Rocky Mountain Section, Flagstaff, Arizona, p.257-295.

Hodder, R. L., Ryerson, D. E., Mogen, R., and Buchholz, J., 1971, Coal mine spoils reclamation research project: Montana Agr. Expt. Sta, Research Rept. 8, 56 p.

Kanizay, S, P,, Obernyer, S. L., and Cattermole, J. M., 1976, Geologic map of the Buffalo area, northwest Powder River Basin, Wyoming: U.S. Geol. Survey Misc. Field Inv. Map MF806 , scale $1: 24,000$.

Karlstrom, T. N. V., Gumerman, G. J., and Euler, R. C,, 1974, Paleoenvironmental and cultural changes in the Black Mesa region, northeastern Arizona, in Karlstrom and others, eds., The geology of northern Arizona with notes on archaeology and paleoclimate: Geol. Soc. America Field Guide Vol. II; 27th Ann. Mtg. Rocky Mountain Section, Flagstaff, Arizona, p. 768-792.

Keefer, W. R., and Hadley, R. F., 1976, Land and natural resource information and some potential environmental effects of surface mining of coal in the Gillette area, Wyoming: U.S. Geo1. Survey Circ. 743, 27 p.

Lee, F. T,, Smith, W. K., and Savage, W. Z., 1976, Stability of highwalls in surface coal mines, western Powder River Basin, Wyoming and Montana: U.S. Geol. Survey Open-File Rept. 76-846, $54 \mathrm{p}$.

Lowry, M. E., and Cummings, T. R., 1966, Ground water resources of Sheridan County, Wyoming: U.S. Geol. Survey Water-Supply Paper 1807, $77 \mathrm{p}$.

Maiss, Francis, 1976, Wild1ife habitat, Campbell County, Wyoming: available from Bureau of Land Management, Buffalo Resource office, Buffalo, Wyoming, 70 p., 5 maps.

McGregor, E. E., 1975, Preliminary study of 
geotechnical properties of the Fort Union Formation from two drill holes near Ashland, Montana: U.S. Geol. Survey Open-File Rept. 75-644, $19 \mathrm{p}$.

Price, Donald, 1976a, Map showing general chemical quality of ground water in the Kaiparowits coal basin area, Utah: U.S. Geol. Survey, Misc. Geol. Investigations Map I-1033-A, in press.

1976b, Map showing general availability of ground water in the Kaiparowits coal basin area, Utah: U.S. Geol. Survey Misc. Geol. Investigations Map I-1033-B, in press.

Sargent, K. A, , and Hansen, D. E., 1976, General geology and mineral resources of the coal area of south-central Utah, with a section on Coal mine subsidence, by C. R. Dunrud: U.S. Geol. Survey Open-File Rept. 76-811, 122 p.

Sharp, W. W., Jr., 1966, Example of stratigraphic confusion: Type locality of Butler Clay Member of Rockdale Formation (Wilcox Group), Bastrop County, Texas: Am. Assoc. Petroleum Geologists Bull., v. 50, no. 7 .
Turner, A. K., 1976, Computer aided environmental impact analysis, Part 1 , Procedures: Colorado School of Mines Industrial Bu11, $v, 19$, no, 2, $23 \mathrm{p}$.

U.S. Congress, 1976, Oversight hearing on federal coal leasing, Mar. 26, Apr, 1 and 5: Washington, D.C., Seria1 No. 94-53, 221 p.

U.S. Department of the Interior, 1976, Code of Federa1 regulations, Title 30, Part 211 Coa1 mining operating regulations; reclamation and performance standards: Federal Register, v. 41, no. 96, May 17, 1976, p. 20252.

U.S. Geological Survey, 1976, Geochemical survey of the western energy lands (third annual progress report, July 1976): U.S. Geol. Survey Open-File Rept. 76-729, 44 p.

U.S. Senate, 1977, Surface mining control and reclamation act of 1977, Senate Bill s-7: 95th Congress, 1st Session, January 10, 1977, $145 \mathrm{~ms}$. pages.

Van Voast, W. A., Hedges, R. B., and Pagenkopf, G. K., 1975, Hydrologic impacts of coal mine effluents and spoils leachates: Montana Acad. Sci., Ft. Union Coal Field Symposium Proc., v. 3, p. 289-303. 